\title{
DIGITALCOMMONS
}

$@$ WAYNESTATE-

Wayne State University

$1-1-2004$

\section{Putting SEC Heat on Audit Firms and Corporate Tax Shelters: Responding to Tax Risk with Sunshine, Shame and Strict Liability}

Linda M. Beale

Wayne State University

\section{Recommended Citation}

Linda M. Beale, Putting SEC Heat on Audit Firms and Corporate Tax Shelters: Responding to Tax Risk with Sunshine, Shame and Strict Liability, 29 J. Corp. L. 219, 266 (2004)

Available at: https://digitalcommons.wayne.edu/lawfrp/291 


\title{
Putting SEC Heat on Audit Firms and Corporate Tax Shelters: Responding to Tax Risk with Sunshine, Shame and Strict Liability
}

\author{
Linda M. Beale*
}

I. INTRODUCTION

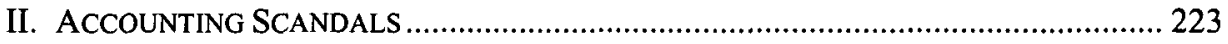

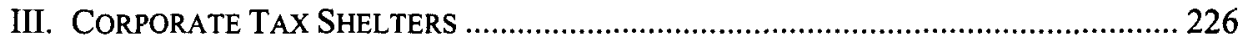

A. Evidence of Corporate Tax Shelter Activity .................................................. 229

1. Enron and Arthur Andersen Redux: Enron's Corporate Tax Shelters...... 232

2. Other Auditors' Tax Shelter Transactions ............................................... 235

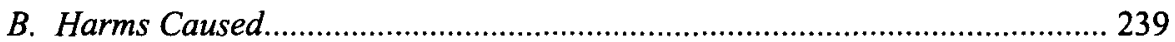

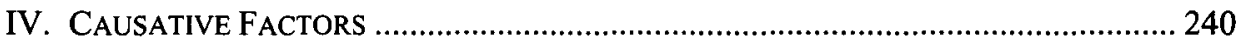

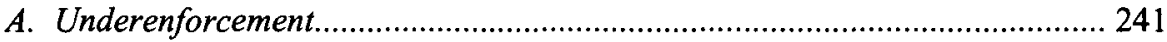

B. Tax Departments as Business Centers ...................................................... 242

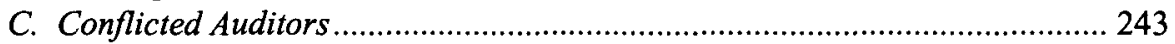

D. Inadequate Information About Risky Transactions ...................................... 246

V. Regulatory RESPonses to the TAX SHELTER Problem ................................. 249

A. Tax Shelter Legislation and Regulations .................................................. 250

B. The Sarbanes-Oxley Auditor Independence Rules ........................................ 255

VI. PROPOSAL FOR A MULTIDISCIPLINARY SEC APPROACH to TAX RISK ….............. 257

A. Ban on Tax Shelter Advising Services....................................................... 258

B. Arming the Audit Committee with Information ............................................. 260

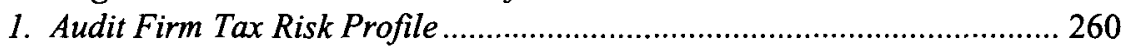

2. Reporting Company Tax Risk Profile..................................................... 262

C. Enhanced Disclosure in SEC Filings........................................................... 263

D. Strict Liability Penalties ........................................................................... 264

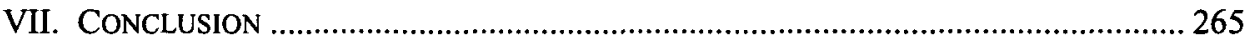

"A tax shelter is 'a deal done by very smart people that, absent tax considerations,

\footnotetext{
* Assistant Professor of Law, University of Illinois College of Law at Urbana-Champaign. I would like to thank John Colombo, Calvin Johnson, Richard Kaplan, Elena Marty-Nelson, Richard Painter, Laurie Reynolds, Larry Ribstein, and the participants at the April 5, 2003 Conference on the Evaluation and Response to Risk in Law and Accounting: $A$ Comparison of the US and EU, at which this Article was first presented, for their helpful comments on earlier drafts. I would also like to thank my University of Illinois College of Law Class of 2003 student assistants for their invaluable help: Michael Stetler, for research assistance, and Robyn Richmond, for discussion of informal consultation between the IRS and SEC.
} 
would be very stupid."'1

\section{INTRODUCTION}

After the fall of Enron and Arthur Andersen, Congress enacted the Sarbanes-Oxley Act of $2002^{2}$ to deal with problems revealed by the accounting scandals. The Securities and Exchange Commission (SEC) moved expeditiously to promulgate rules on core issues such as auditor independence ${ }^{3}$ and professional standards for attorneys practicing before the SEC. ${ }^{4}$

The Treasury Department (Treasury) and the Internal Revenue Service (IRS) have encountered corporate tax compliance problems similar to the accounting scandals. ${ }^{5}$ Anecdotal evidence among tax practitioners, a flurry of litigation, and anonymous tips suggest that potentially abusive tax-motivated transactions are commonplace. These compliance problems harm participating corporations and investors (not to mention the federal fisc) in much the way that accounting malfeasance does. ${ }^{6}$ Tax shelter planning fees, legal defense costs, and interest and penalties may impact a corporation's liquidity, debt service costs, and stock prices. Revelation of corporate and executive tax problems, as in the case of ImClone and Sprint, can have ripple effects on management structure and investor confidence.

Factors similar to those underlying accounting scandals may encourage abusive tax planning. ${ }^{7}$ The IRS is underfunded and understaffed, resulting in inadequate enforcement. As in the case of the internal finance and accounting departments that have moved from gatekeepers to profit centers, corporate tax departments have expanded beyond their primary service role-ensuring compliance with tax rules-to become profit centers that design novel ways to circumvent those rules. Corporations can hide aggressive tax planning in aggregate numbers on tax returns and financial statements. Company directors either are uninformed about, or acquiesce in, potentially abusive tax planning. Audit firms do not highlight these issues for directors or investors and, in some cases, actively assist in designing aggressive tax shelters for lucrative fees.

Abusive tax and accounting gimmicks sometimes go hand-in-hand. ${ }^{8}$ Tax savings boost book revenues. Corporations that engage in sham tax transactions may be more likely to take questionable accounting positions, and auditors that promote abusive tax shelters may be more likely to acquiesce in abusive accounting. The rapid expansion of

1. Tom Herman, Tax Report, Wall St. J., Feb. 10, 1999, at Al (quoting Michael Graetz).

2. Public Company Accounting Reform and Investor Protection Act of 2002, Pub. L. No. 107-204, 116 Stat. 745 (2002) [hereinafter Sarbanes-Oxley or the Act].

3. Final Rules: Strengthening the Commission's Requirements Regarding Auditor Independence, Release Nos. 33-8183, 34-47265, 35-27642, IC-25915, IA-2103, FR-68; File No. S7-49-02 (Jan. 28, 2003) [hereinafter FINAL RULES], available at http://www.sec.gov/rules/final/33-8183.htm (last visited Oct. 15, 2003).

4. Final Rule: Implementation of Standards of Professional Conduct for Attorneys, Release Nos. 338185, 34-47276, IC-25919; File No. S7-45-02 (Jan. 29, 2003), available at http:/www.sec.gov/rules/final/338185.htm (last visited Oct. 15, 2003).

5. See infra notes $15-103$ and accompanying text.

6. See infra notes 104-112 and accompanying text.

7. See infra notes 113-147 and accompanying text.

8. See infra note 16 (Enron's accounting gimmicks), notes $60-78$ (Enron), and note 97 (HealthSouth) and accompanying text. 
accounting firms into multidisciplinary practice areas facilitates companies' participation in tax shelters and undermines directors' and investors' assessments of tax risks.

Congress has taken steps to limit tax shelters. In some cases where Congress has identified a particular abuse, it has enacted provisions to disallow the purported tax benefit in future transactions. ${ }^{9}$ Particularized responses, however, cannot adequately address shelter design in a rule-based system: when one shelter is disallowed, the tax shelter industry merely revamps designs to purport to satisfy a slightly different set of rules. For this reason, 1997 legislation ${ }^{10}$ focused on enhancing tax enforcement through transparency. It required companies and promoters to register certain tax-avoidance transactions and to report tax-structuring information to the IRS in connection with other transactions with characteristics that suggest the possibility of an abusive tax shelter. Corporate tax shelter regulations setting forth the requirements for that disclosure have now been finalized. ${ }^{11}$

Despite these developments, auditors continue to design tax shelters for corporate clients and their executives. In passing Sarbanes-Oxley, Congress missed an opportunity to address the impact of these tax services on auditor independence and corporate governance. ${ }^{12}$ The Act itself did not unambiguously prohibit any tax consulting that an auditor might provide an audit client. Although the SEC's adopting release for auditorindependence rules suggests that audit committees should not approve auditor tax services for transactions that lack a business purpose, the only non-audit tax service that the rules unambiguously prohibit is auditor representation of audit clients on tax issues in court proceedings. ${ }^{13}$ Recent SEC staff guidance on pre-approval of tax services is insufficient.

This Article argues that the SEC's approach to tax services failed to respond adequately to the multidisciplinary expansion of accounting firms. In particular, this Article contends that the inadequacy of audit committees' information about audit firms hinders their ability to perform key functions of selecting auditors and approving nonaudit tax services. Similarly, directors likely have insufficient information about a reporting company's tax risks to permit effective monitoring of internal tax and accounting functions or company participation in potentially abusive tax transactions. Those information asymmetries also leave investors without tax risk information that would otherwise factor into investment decisions.

To address these problems, this Article proposes a multidisciplinary approach to protection of the securities markets. Specifically, the Article urges the SEC (through the new oversight board created by Sarbanes-Oxley) to ban auditor provision of certain tax services. These rules need not invent a separate, SEC-generated definition of problematic tax shelters. They can simply adopt, by cross-reference, the reporting categories for corporate tax shelters established in the IRS's corporate tax shelter regulations. Those regulations already require companies and their tax advisers to determine whether contemplated transactions must be reported to the IRS. SEC adoption of the same reporting categories would provide an easily administrable way to ban auditor provision

9. See infra note 153 and accompanying text.

10. See infra note 160 and accompanying text.

11. T.D. 9046, 2003-12 I.R.B. 614 .

12. See infra note 182 and accompanying text.

13. See infra notes $184-189$ and accompanying text. 
of tax services that are most likely to create conflicts of interest, at minimal cost to auditors and reporting companies.

Internal tax risk disclosure based on the IRS reporting categories can also enhance company directors' decision-making. The SEC should require two types of internal disclosure. First, auditors should provide an "audit firm tax risk profile" to the directors. The audit firm profile provides objective information about an audit firm's history in designing, promoting, or implementing potentially abusive tax transactions. It includes a "cumulative failure rate" for certain tax shelters designed, promoted, or implemented by the audit firm for any of its clients. This statistic provides a comparative yardstick that would permit audit committees to assess auditors' competence to evaluate tax risk. ${ }^{14}$ Second, company directors should receive a similar "reporting company tax risk profile" that provides objective information about a company's own participation in aggressive tax transactions and its "cumulative failure rate" in those transactions. This information would permit directors to intervene to prevent a misallocation of corporate resources to overly aggressive tax planning. These two tax risk profiles would arm audit committees to make better decisions. As an additional benefit, the profiles would counter the tendency of auditors to acquiesce in promoters' analysis of aggressive tax transactions, thus helping to ensure that external auditors provide independent assessment of contingent tax liabilities for reporting company tax transactions that have been structured by other tax advisers.

This Article also proposes that the SEC require public disclosure based on these tax risk profiles. Disclosure would provide investors with information about the risk in a reporting company's tax planning strategies and the credibility of its external auditor on tax matters. The enhanced transparency should remove information asymmetries that currently limit investors' ability to assess tax risks, resulting in more efficient markets.

Finally, to reinforce the new disclosure requirements and to further ensure that auditors independently assess reporting company transactions designed by other tax advisers, this Article proposes a series of strict liability penalties. These penalties should be sufficiently high to deter non-disclosure and encourage adequate review.

The aim of the proposals is to let the sun shine brightly on tax shelter planning through enhanced internal disclosure to audit committees of auditor and reporting company tax risk profiles, to shame the participants and purveyors of potentially abusive tax shelter transactions through public disclosure of tax shelter cumulative failure rates, and to impose strict liability penalties for violations of SEC disclosure rules and gross understatements of tax accruals. These proposals are intended to ensure that audit committees can perform their functions and that investors can overcome information asymmetries relating to tax risks.

These proposals do not put the SEC in the position of enforcing tax laws. They merely permit the SEC to use the IRS's existing tax analysis to set appropriate limits on auditor provision of tax services. Even when non-audit tax services are permitted, the proposals provide a means for directors and investors to assess the competence of audit firms and the aggressiveness of reporting companies' tax positions. As an incidental

14. In other words, an auditor's cumulative failure rate, even if numerically low, would provide a relative measure of competence when considered in comparison to the cumulative failure rates of other accounting firms that provide non-audit tax advice. 
benefit, this enhanced transparency should result in more prudent tax planning and better tax compliance by reporting companies, removing a further market-distorting effect of aggressive tax shelters.

The argument proceeds as follows. Part II briefly reviews the accounting scandals and the regulatory and congressional response culminating in the Sarbanes-Oxley auditor independence rules. Part III lays out the evidence of a similar corporate tax compliance problem that impacts audit reliability and investor assessment of company profitability. Part IV considers potential causes of these tax compliance failures, drawing on parallels with the accounting scandals. Part V briefly reviews congressional and Treasury responses to abusive corporate tax planning. The discussion focuses on the development of new disclosure requirements and the inadequate attention to auditor-provided tax services in the context of the development of the Sarbanes-Oxley auditor independence rules. Part VI proposes explicit measures to enhance auditor independence. The Article suggests that the market aspects of tax risks can be addressed at nominal cost to audit firms and reporting companies by building on what the Treasury has already accomplished in defining potentially abusive tax transactions and establishing registration and reporting requirements. Accordingly, the Article proposes an explicit bright-line rule for banning certain tax planning services and develops an integrated proposal for providing appropriate tax risk disclosure to directors and investors. Part VII concludes by considering additional tax issues that may respond to a multidisciplinary SEC approach.

\section{ACCOUNTING SCANDALS}

Over the last two years, publicly held companies have reported record earnings restatements. ${ }^{15}$ Enron's meltdown is symbolic. The Enron bankruptcy examiner

15. See, e.g., House Committee on Financial Services, The Sarbanes-Oxley Act: The First Year 7 (July 29, 2003), available at http://financialservices.house.gov/news (last visited Oct. 15, 2003) (citing most recent Huron Consulting Group study showing that restatements "climbed by 53\% since 1999, while the number of publicly held companies has actually decreased by 14\%"); Neil Irwin, Making It All Add Up, Again, WASH. POST, Apr. 28, 2003, at E01 (citing a Huron Consulting Group study that showed 330 public companies restated results in 2002, up from 270 in 2001 , even though there was a decline in the number of public companies); HuRON CONSUlting GROUP RELEASES, 2003 RESTATEMENTS RESUlts (June 29, 2003), available at http://www.huronconsultinggroup.com (last visited Mar. 24, 2004) (announcing Interim 2003 Restatements Study showing decline in number of reporting companies and increase in restatements). Illustrative accounting scandals include (i) Bristol-Myers, audited by PricewaterhouseCoopers, restatement of $\$ 2.75$ billion; (ii) Symbol Technologies Inc., audited by Deloitte Touche LLP, sales overstated by as much as $\$ 250$ million; (iii) Royal Ahold, audited by Deloitte, more than $\$ 900$ million; (iv) Rite Aid, audited by KPMG, civil fraud charges for 1997-1999 financial statements; (v) Xerox, audited by KPMG, $\$ 1.42$ billion in inflated earnings between 1997 and 2000; and (vi) HealthSouth Corporation, audited by Ernst \& Young, more than \$2.5 billion in inflated eamings. See, e.g., Gardiner Harris, Bristol-Myers Says Accounting Was 'Inappropriate, 'Inflated Sales, WALL ST. J., Mar 11, 2003, at A2 (Bristol-Myers); U.S. General ACCOUNTING OfFice, FinanCial STATEMENT RESTATEMENTS: TRENDS, MARKET IMPACTS, REGULATORY RESPONSES, AND REMAINING CHALlENGES, GAO03-138 at 183 (Oct. 2002) [hereinafter GAO REPORT] (Rite Aid); id. at 226 (Xerox); Jonathan D. Glater, HealthSouth Looks Deeper Into Its Books, N.Y. TIMES, Jul. 12, 2003, at C1 (HealthSouth); John M. Berry, Ahold Uncovers Further Mistakes; Profit Overstatements Now at $\$ 909$ Million, WASH. POST, May 27, 2003, at EO1 (Royal Ahold); Alex Berenson, Ex-Symbol Official Admits Scheme, N.Y. TIMES, Mar. 26, 2003, at C2 (Symbol Technologies). See also Corporate Scandal Primer, Washingtonpost.com, available at http://www.washingtonpost.com/wp-srv/business/scandals/primer/index.html (last visited Oct. 20, 2003) (providing an interactive overview of various accounting scandals). 
concluded that Enron's use of accounting gimmicks with special purpose entities allowed it to "so engineer[] its reported financial position and results of operations that its financial statements bore little resemblance to its actual financial condition or performance."16 Arthur Andersen, Enron's external auditor, played a central role in Enron's accounting-driven transactions, ${ }^{17}$ as well as a number of other accounting irregularities. 18

Costs of accounting scandals mount quickly. They include legal and investigative costs, ${ }^{19}$ damages in securities lawsuits, ${ }^{20}$ inability to pass costs on to insurers, ${ }^{21}$ liquidity problems and higher debt service costs, ${ }^{22}$ and rating agency downgrades. ${ }^{23}$ The Enron debacle is a prime example of the cascading effect of accounting irregularities: total loss of investor confidence, the implosion of its long-term auditor, and, ultimately, bankruptcy. 24

16. In $r e$ Enton Corp., SECOND INTERIM REPORT OF NEAL BATSON, COURT-APPOINTED EXAMINER, No. 01-16034 (AJG), at 15 (Bankr. S.D.N.Y. Jan. 21, 2003) [hereinafter ENRON BANKRUPTCY REPORT]. See also id. at 3 (reporting that " $96 \%$ of Enron's reported net income and $105 \%$ of its reported funds flow from operations were attributable to ... six accounting techniques... [without which] Enron's reported debt at December 31, 2000 , would have been $\$ 22.1$ billion rather than $\$ 10.2$ billion"). The techniques-"FAS 140 Transactions," "Tax Transactions," "Non-Economic Hedges," "Share Trust Transactions," "Minority Interest Transactions," and "Prepay Transactions"-are described in detail on pages 36-45 of the report. An example involving shortterm circular cash flows is described as follows: "Enron borrowed $\$ 500$ million, bought Treasury securities with it, sold the Treasury securities, recognized $\$ 500$ million of operating cash flow, and repaid the loan-all within 30 days straddling its 1999 year end-and without reflecting the loan as debt on its financial statements." Id. at 28.

17. See, e.g., id. at 39 (discussing Andersen's role in planning a technique designed to be treated as a sale even though the economic substance did not comport with a sale); Harold S. Peckron, Watchdogs That Failed to Bark: Standards of Tax Review After Enron, 5 FLA. TAX. REV. 851, 861 (2002) [hereinafter Watchdogs] (noting Andersen's "extensive participation and structuring advice").

18. A sampling of Andersen's accounting failures includes (i) the 1999 accounting fraud at the Baptist Foundation of Arizona, (ii) the 2001 SEC charge against Sunbeam covering accounting gimmicks in financial statements from 1996 through 1998; (iii) Global Crossing Ltd.'s restatements; (iv) WorldCom's \$11 billion earnings restatements; and (v) Waste Management, Inc.'s $\$ 1.32$ billion restatement and eventual collapse. See, e.g., GAO REPORT, supra note 15, at 201 (Sunbeam); id. at 215 (Waste Management); Marianne M. Jennings, $A$ Primer on Enron: Lessons From A Perfect Storm of Financial Reporting, Corporate Governance and Ethical Culture Failures, 39 CAL. W. L. REv. 163, 215 (2003) (Global Crossing and Baptist Foundation of Arizona, among others); Bamaby J. Feder, Management Practice Enabled Huge Fraud. 2 Investigations Find, N.Y. TIMES, June 10, 2003, at $\mathrm{Cl}$ (WorldCom $\$ 9$ billion restatement possibly increasing to $\$ 11$ billion).

19. See, e.g., Dennis K. Berman, Qwest is Spending Top Dollar to Defend Accounting Practices, WALL ST. J., Mar. 10, 2003, at C1 (indicating that Qwest spent $\$ 75$ million in 2002 for outside attorneys in connection with accounting problems, while Rite Aide spent about $\$ 82$ million for investigating accounting irregularities in 2001).

20. Kara Scannell, Class Settlements in Securities Cases Rose 50\% in '02, WaLl St. J., Apr. 10, 2003, at $\mathrm{C} 13$ (citing a study by Cornerstone Research finding that "total damages recovered in settlements in 2002 rose $50 \%$ to $\$ 2.4$ billion from $2001 ")$.

21. See Berman, supra note 19 (reporting on insurers' attempt to rescind $\$ 325$ million of coverage for $\$ 400$ million costs, on the grounds that Qwest misled them).

22. See, e.g., Gregory Zuckerman, Cash Drought: A Dwindling Supply of Short-Term Credit Plagues Corporations-Market in Commercial Paper is Hurt by Enron Fears, WALL ST. J., Mar. 28, 2002, at A1 (indicating that the Enron debacle caused "financial jitters" that reduced the supply of short-term commercial paper and forced companies to turn to other sources of funding at higher interest).

23. Id.

24. See generally ENRON AND BEyond: TeChNicAl ANAlysis of Accounting, Corporate 
A number of causative factors played a role in the accounting scandals. ${ }^{25}$ Internal finance staffs and directors lost sight of their objective of protecting investors. ${ }^{26}$ The rapid expansion of lucrative auditor consulting services ${ }^{27}$ and growth of multidisciplinary accounting firms ${ }^{28}$ created serious conflicts of interests. ${ }^{29}$ The accounting profession's self-regulatory process, funded by the American Institute of Certified Public Accountants (AICPA),${ }^{30}$ could not eliminate harmful practices. ${ }^{31}$ Lack of resources for rigorous SEC enforcement likely abetted opportunistic circumvention of the rules. ${ }^{32}$ Inadequate and

GovernanCE, AND SeCuRITIES Issues (Julia K. Brazelton \& Janice L. Ammons eds., 2002) [hereinafter ENRON AND BEYOND] (discussing these issues).

25. See John C. Coffee Jr., What Caused Enron?: A Capsule Social and Economic History of the 1990s, 89 CORNELL L. REV. 269, 269-71 (2003) (acknowledging the role played by various moral and ethical weaknesses, such as weakened business ethics, "infectious greed," “'rogue' managers," and "negligent, inattentive boards of directors"). See also BARBARA LEY TOFFLER WITH JENNIFER REINGOLD, FINAL ACCOUNTING: AMBITION, GREED AND THE FALl of ARTHUR ANDERSEN (Broadway Books 2003) [hereinafter FinAL ACCOUNTING] (discussing the self-reinforcing effect of these factors in creating a climate that fosters integrity or encourages rogue behavior).

26. 'The 'watchdogs,' 'gatekeepers,' and 'protectors of the public interest' were instrumental in providing the cover that allowed the [financial statement] misrepresentations to grow and fester." Mark Cheffers, Enron and Wall Street, in ENRON AND BEYOND, supra note 24, at 301-02.

27. See, e.g., FINAL ACCOUNTING, supra note 25 , at 169 (describing the growth of accountants' consulting business). In many of the cases in which companies restated earnings, they paid significant fees to their external auditors for non-audit consulting services. See id. at 156 (stating that WorldCom paid Andersen $\$ 12.4$ million in non-audit fees in a representative year); id. at 148 (stating that Waste Management paid Andersen $\$ 48$ million in audit fees and $\$ 31$ million in non-audit fees in 2000).

28. See Cassell Bryan-Low, More Ernst Nonaudit Services Under Fire, WaLl ST. J., Mar. 10, 2003, at C1 (regarding captive law firm McKee Nelson Ernst \& Young).

29. These conflicts undermine the essential auditor role enunciated in United States v. Arthur Young, 104 S. Ct. 1495, 84-I USTC | 9305 (1984), aff'g, rev'g and remanding 82-1 USTC If 9320 (2d Cir. 1982) (stating that an auditor must "maintain total independence from the [audit] client at all times and [give] complete fidelity to the public trust"). The SEC has emphasized the importance of independence in its recent actions. For example, in a disciplinary proceeding seeking a six-month suspension of Ernst \& Young, the SEC alleged that the audit firm's internal controls lacked key features necessary to ensure auditor independence. See Cassell Bryan-Low \& Jonathan Weil, SEC Calls Ernst \& Young's Internal Controls Inadequate, WaLL ST. J., May 30, 2003, at C1.

30. The AICPA's website provides general information about the group and related bodies such as the Financial Accounting Standards Board (FASB). See http://www.aicpa.org. See also Public Oversight Board, About the $P O B$, available at http://www.publicoversightboard.org/about.htm (last visited Oct. 15, 2003) (describing the AICPA's establishment of a practice section for firms that audit SEC registrants and an oversight board, funded solely by the AICPA but made up of non-accountants, to oversee the practice section).

31. See, e.g., Senate Debate on The Public Company Accounting Reform and Investor Protection Act of 2002, S. 2673, 148 CONG. REC. S6734, at 6749 (July 15, 2002) (statement of Sen. Grassley) (pointing out the futility of "industry-wide self-checking"); ARTHUR LEVITT WITH PAULA DWYER, TAKE ON THE STREET: WHAT Wall STREET AND CORPORATE AMERICA DON'T WANT YOU TO KNOW; What YOU CAN Do to Fight BaCK 107 (Pantheon Books 2002) [hereinafter THE STREET] (noting inability of standard-setting process to keep pace with the numbers games).

32. See, e.g., U.S. General accounting Office, Human Capital: Major human Capital Challenges at SEC AND Key Trade Agencies, GAO-02-662T 3 (Apr. 23, 2002) (stating that increases in workload have outpaced SEC increases in staff resources and finding that, on an activity basis, "over the last decade staffing within the various areas of SEC's regulatory oversight grew between 9 and 166 percent, while workload in those same areas grew from 60 to 264 percent"); James D. Cox \& Randall S. Thomas, SEC Enforcement Actions for Financial Fraud and Private Litigation: An Empirical Inquiry, DUKE L.J. (forthcoming 2003), available at http://ssrn.com/abstract_id-429140 (indicating, at 12-14 in the SSRN version, 
misleading public information meant the market could not self-correct.

Congress responded to the wave of accounting scandals with Sarbanes-Oxley. Among other changes, Sarbanes-Oxley replaced the accounting profession's selfregulatory mechanism with a new government oversight board, the Public Company Accounting Oversight Board (PCAOB). ${ }^{33}$ The Act also established a non-exclusive statutory list of eight banned categories of non-audit services and authorized the PCAOB to add to the list by regulation. ${ }^{34}$

\section{CORPORATE TAX SHELTERS}

Over the last three years, while accounting scandals captured media coverage and public outrage, Treasury and the IRS focused their attention on a similar compliance

that understaffing and underfunding limit both reviews and enforcements). But see U.S. General Accounting Office, SEC Enforcement Program: Information on Productivity Statements and Cases Closed Without Action, GAO-86-106BR (Aug. 1986), at 19 (stating that "there is no reliable method for estimating the amount of violative conduct the SEC has prevented").

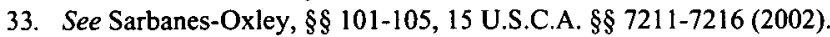

34. See Sarbanes-Oxley $\S 201(\mathrm{~g})(1)-(9), 15$ U.S.C.A. $\S 78 \mathrm{j}-1$ (2002) (amending Section 10A of the Securities Exchange Act of 1934 by prohibiting the provision of bookkeeping, financial information services design, appraisal or valuation services, actuarial services, internal audit outsourcing services, management and human resources services, broker-dealer and investment banking services, legal and expert services unrelated to the audit, and "any other service that the Board determines, by regulation, is impermissible"). The prohibited services were viewed as representing serious conflicts of interests under principles providing that an auditor should not "audit its own work," "function as part of the management or as an employee of the audit company," "act as an advocate of the audit client," or "be the promoter of the audit client's stock or other financial interest." 148 CONG. REC. S6327, 6332 (daily ed. July 8, 2002) (statement of Sen. Sarbanes). See also 148 CONG. REC. S7363 (July 25, 2002) (statement of Sen. Sarbanes) (stating that the principles determined the list of banned services); REPORT OF THE SENATE COMMITTEE ON BANKING, HOUSING AND URBAN AFFAIRS TO ACCOMPANY S. 2673, S. Rep. No. 107-205, at 18 (2002) (highlighting importance of the first three principles in determining whether a service should be prohibited). For a more extensive discussion of the Act's provisions, see Richard L. Kaplan, The Mother of All Conflicts: Auditors and Their Clients, 29 J. CoRP. L. 363 (2004) (focusing on three significant problems and the shortcomings in the Sarbanes-Oxley responses); Linda M. Beale, Developments May Lead SEC to Ban Certain Tax Services Under Sarbanes-Oxley Independence Rules, 16 J. TAX'N FIN. INST. 5, 5-15 (May 2003) (addressing auditor independence issues when auditors provide nonaudit tax services). See generally William W. Bratton, Enron, Sarbanes-Oxley and Accounting: Rules Versus Standards Versus Rents, 48 VILL. L. REV. 1023 (2003) (arguing that Enron's collapse was due to auditor failure, not the inadequacy of a rules-based accounting system compared to a standards-based accounting system); Lawrence A. Cunningham, The Sarbanes-Oxley Yawn: Heavy Rhetoric, Light Reform (And It Might Just Work), 35 U. CONN. L. REV. 915, 928 n.46 (2003) (suggesting that the Act deals with very specific problems rather than "systemic infirmities" and does not go much beyond the auditor independence standards already established by the SEC under former chair Arthur Levitt, but considering that it may focus attention appropriately on the importance of the monitoring function); Jennings, supra note 18, at 255 (calling SarbanesOxley a "codification of moral standards for businesses, while providing the teeth for ensuring that those morals are understood and followed"); Michael A. Perino, Enron's Legislative Aftermath: Some Reflections on the Deterrence Aspects of the Sarbanes-Oxley Act of 2002, 76 ST. JOHN'S L. REV. 671, 672-74, 680 (2002) (calling the law "disorganized," with criminal provisions that "represent little more than political grandstanding" yet judging that the law, if read broadly, could result in "significant extensions of obstruction law"). Neither the Act nor the final rules changed the general standard for independence that considers an auditor independent only if "capable of exercising objective and impartial judgment on all issues encompassed within the accountant's engagement," determined by taking into consideration "all relevant circumstances." Reg. S-X, Rule 2-01(b), 17 C.F.R. $\S 210.2-01$ (b) (2003). 
problem-corporate tax shelters. ${ }^{35}$ Although tax practitioners, academics and government officials may not agree on a specific definition of an abusive corporate tax shelter, there is consensus that abusive transactions are undertaken for purposes that are not germane to a taxpayer's business in order to reduce taxes on unrelated income. ${ }^{36}$ In a rule-based system, there is significant opportunity for transaction design around the rules. ${ }^{37}$ Aggressive tax-avoidance transactions purport to comply with tax laws by

35. Corporate tax shelters came into full focus with the Clinton Administration's FY 2000 budget submission, which included action on corporate tax shelters as revenue-raising provisions. See GENERAL EXPLANATION OF THE ADMINISTRATION's REVENUE PROPOSALS, DEPARTMENT OF THE TREASURy, Feb. 1999, at 95-105. Further impetus came from the Joint Committee on Taxation's analysis of corporate tax shelters in the context of its study of penalty and interest provisions. STAFF OF THE JOINT COMMITTEE ON TAXATION,

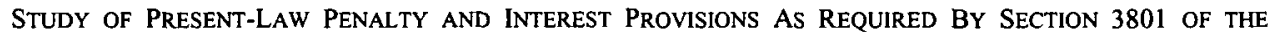
INTERNAL REVENUE SERVICE RESTRUCTURING AND REFORM ACT OF 1998 (INCLUDING PROVISIONS RELATING To CORPORATE TAX SHELTERS), JCS-3-99, at Vol. I, 173-250, July 22, 1999 [hereinafter JCT PENALTY STUDY] (identifying characteristics of corporate tax shelters, factors in the proliferation of shelters, and possible enhancements for sanctions). The Treasury also undertook a complete analysis of corporate tax shelters. Treasury Department, The Problem of Corporate TaX Shelters: Discussion, analysis and Legislative Proposals (July 1999) [hereinafter Treasury StUdY]. The IRS also began to realize some success in litigating corporate tax shelter cases. See, e.g., ACM Partnership v. Commissioner, 157 F.3d 231 (3d Cir. 1998), aff'g in part and rev'g in part 73 T.C.M. 2189 (1997) (finding no economic substance in a contingent installment note sales arrangement designed to generate artificial losses to offset a large capital gain at Colgate); ASA Investerings Partnership v. Commissioner, 201 F.3d 505 (D.C. Cir. 2000), aff'g 76 T.C.M. 325 (1998) (similar); Winn-Dixie Stores, Inc. v. Commissioner, 113 T.C. 254 (1999), aff'd per curiam 254 F.3d 1313 (11th Cir. 2001) (disallowing interest deductions in respect of a corporate-owned life insurance transaction). See also United States v. Arthur Andersen, 2002 TNT 186-14 (N.D. Ill. Sept. 23, 2002) (IRS suit to enforce summons for tax shelter information).

36. See, e.g., Tom Herman, When a Tax Shelter Goes From Legal To 'Abusive,' Wall ST. J., Apr. 2, 2003, at D3 (quoting Sullivan \& Cromwell tax partner David Hariton describing an abusive tax shelter as "a transaction with minimal economics that allows a taxpayer to claim an unintended deduction or loss and use it to offset the tax on unrelated income"); Susan Beck, Gimme Shelters, 21 AM. LAw. 10, 105, 110 (1999) (quoting Harold Handler, former chair of the New York State Bar Association Tax Section, describing tax shelters as "aggressive" and "artificial" "vehicles marketed to provide corporations with artificial losses"); Peter C. Canellos, Guidelines for a Conscientious and Effective Tax Practice, Mar. 2003 TAXES 281, 284-85 (discussing tax shelter practice as one in which "people [are] in the business of generating a product to reduce taxes, and the product is generated before there is a business transaction" where "you start with a tax gimmick, and then try to add a qualifying business purpose and economic substance").

37. There is considerable commentary on the differences between rule-based and standard-based systems, especially in the accounting literature. See, e.g., Bratton, supra note 34 (considering whether rules-based accounting created problems that led to Enron, compared to a standards-based accounting system); SEC OFFICE OF THE Chief Accountant, Study PuRsuant to SeCtion 108(D) OF THE SARBanes-OXLEy ACt OF 2002 ON the Adoption by the United States Financial Reporting SyStem of a PRINCIPLEs-Based ACCOUNTING SYSTEM, July 25, 2003, Executive Summary at 6, available at http://www.sec.gov/news/studies/principlesbased stand.htm (last visited Oct. 15, 2003) (contrasting principles-based standards with rules-based standards and noting that rules-based standards can "reward those willing to engineer their way around the intent of standards"); Kip Betz, Accounting: McDonough Says Principles-Based Standards, Capital Accord Will Widen Economic Harmony, 24 Daily Tax Rep. at G6 (Feb. 5, 2003) (summarizing McDonough's comments supporting principles-based accounting standards at a Bond Market Association conference). In the tax commentary, the discussion generally contrasts specific tax rules (e.g., the passive loss rules) with broader antiabuse standards or doctrines (e.g., the various judicial doctrines such as sham transaction, business purpose, and economic substance). See, e.g., infra note 39 (articles on economic substance). See generally John B. Braithwaite, Rules and Principles: A Theory of Legal Certainty, 27 Australian J. OF Legal PhiL. 47 (2002) (theorizing that precise rules result in less certainty as the regulated phenomena become more complex). 
applying mechanistic, literal interpretations to innovative structures but operate to circumvent the purposes of the tax laws to achieve particular tax benefits. ${ }^{38}$ The arrangements often purport to duplicate an allowable deduction or generate an artificial tax loss that does not correspond to an economic loss. ${ }^{39}$ Offsetting gains are generally allocated to a tax-indifferent accommodation party that is paid a fee for participating in the transaction. ${ }^{40}$ In most cases, a reasonable businessperson would refuse to enter into

38. See, e.g., Rev. Rul. 99-14, 1999-1 C.B. 835 (describing a lease-in, lease-out tax shelter, in which a publicly traded domestic corporation made an $\$ 89$ million upfront lease payment to lease a foreign property that was immediately subleased back to the foreign lessor; the taxpayer was at no economic risk because of the offsetting leaseback and benefited from lease payment deductions over the first six years of the arrangement, as well as interest deductions, all at the nominal cost of supplying a minority portion of a required prepayment amount from the taxpayer's own funds; the majority of the prepayment amount was funded with nonrecourse debt). A recent study of Enron condemns the spreading "ethic of technical compliance," which it views as originating in the tax area where structuring solely to reduce taxes has come to be seen as acceptable. William H. Widen, Enron at the Margin, 58 Bus. LAW. 961, 965 n.23 (2003).

39. See, e.g., JOINT COMMITTEE ON TAXATION, REPORT OF INVESTIGATION OF ENRON CORPORATION AND

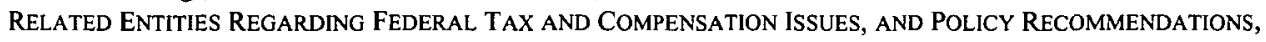
Vols. I, II, and III, (JCS-3-03), Feb. 2003 [hereinafter JCT REPORT]. Lack of economic substance has long been considered a key indicator of corporate tax shelters, and both Congress and academics have discussed the importance of the economic substance doctrine in fighting tax shelters. See, e.g., Calvin H. Johnson, H.R.

The Anti-Skunk Works Corporate Tax Shelter Act of 1999, 84 TAX NOTES 443 (1999) (proposing codification of the economic substance doctrine and offering some procedural provisions to curb tax shelters); Symposium, Business Purpose, Economic Substance, and Corporate Tax Shelters, 54 SMU L. REV. 1, 1-237 (2001) (including commentary by Christopher H. Hanna, Ellen P. Aprill, Steven A. Bank, Peter C. Canellos, David A. Weisbach, Graeme S. Cooper, Mark P. Gergen, Joseph Bankman, Alan Gunn, Lawrence Zelenak, Martin J. McMahon Jr. and George K. Yin); Martin J. McMahon, Jr., Beyond a GAAR: Retrofitting the Code to Rein in $21^{\text {st }}$ Century Tax Shelters, 98 TAX NOTES 1721 (2003) (urging codification) [hereinafter Beyond a GAAR]; american Bar ass'n, Section of Taxation, Comments on the Proposed Codification of the ECONOMIC SUBSTANCE Doctrine (Letter from Herbert Beller to Sens. Grassley \& Baucus dated April 24, 2003), reprinted in 2003 TNT 81-74 (Apr. 28, 2003) (comments on codification); David P. Hariton, How To Fix Economic Substance, 99 TAX NOTES 539 (2003) (discussing current codification proposal); Samuel C. Thompson Jr. \& Robert Allen Clary, Jr., Coming In From the 'Cold': The Case For ESD Codification, 99 TAX NOTES 1270 (2003) (concluding that arguments against codification are not convincing); James M. Peaslee, Letters to the Editor: Economic Substance Codification Debate: Fun With Fallacies, 99 TAX NOTES 1567 (2003) (arguing that there is no basis for deciding when particular tax benefits are "clearly contemplated" by the Code); David P. Hariton, Viewpoints: Stop Calling It Economic Substance, 99 TAX NOTES 1543 (2003) (arguing that the discussion should focus on defining tax shelters and agreeing on appropriate treatment rather than codification of economic substance); N.Y. STATE BAR ASS'N SECTION OF TAXATION, ECONOMIC SUBSTANCE CODIFICATION (report submitted to administration officials on May 21, 2003), reprinted in 99 TAX NOTES 1829 (2003) (comments on codification proposal); Terrill A. Hyde \& Glen Arlen Kohl, Letters to the Editor, The Shelter Problem is Too Serious Not to Change the Law, 100 TAX NOTES 119 (July 7, 2003) (arguing for codification).

40. See, e.g., Joseph Bankman, The New Market in Corporate Tax Shelters, 83 TAX NotES 1775, 1777 (June 21, 1999) [hereinafter New Market] (describing characteristics of typical tax shelter transactions); TREASURY STUDY, supra note 35, at 14-17 (same). Accommodation parties such as foreign banks or tax-exempt pension funds often receive fee payments for participating in a shelter transaction in a role that is necessary to achieve the purported tax benefits. The FLIP/OPIS shelter sold by KPMG used foreign banks as accommodation parties in a transaction where shares owned by a foreign bank were redeemed, purportedly resulting in basis shifting from those shares to the taxpayer's interest in the same corporation. See Joseph J. Jacoboni v. KPMG LLP, No. 6:02-cv-510-Orl-22DAB (D.C.M.D. filed Fla. June 5, 2002), Second Am. Compl. at $\{9,30$, available at http://pubs.bna.com/ip/BNA/TXC.NSF/837911c53cc9d29185256498006894bf/95e17e90 $0086054 \mathrm{c} 8525 \mathrm{bcc} 7000 \mathrm{fe} 440$ ?OpenDocument (last visited Feb. 27, 2004) [hereinafter Jacoboni Complaint] (providing further discussion of this shelter). Foreign banks also served as accommodation parties in the 1997 
the transaction if the purported tax benefits were not available. ${ }^{41}$

The following Subparts examine corporate tax shelters to the extent necessary to identify issues relevant to reporting company audits. Subpart A summarizes evidence on the scope of the corporate tax shelter problem and briefly reviews some specific transactions to illustrate the players involved and the way such transactions develop. Subpart B considers the similar economic and market distortions resulting from abusive tax shelters and accounting malfeasance.

\section{A. Evidence of Corporate Tax Shelter Activity}

With the surge in new derivative financial instruments ${ }^{42}$ in the late 1980 s and early 1990s, large corporate tax departments became fertile hunting grounds for those interested in hawking transactions purporting to defer or eliminate tax liability. ${ }^{43}$ Derivatives spurred shelter development by facilitating "off-the-shelf" transactions that presented no real business risk because they did not require actual purchase and holding of hard assets. ${ }^{44}$ Anecdotal evidence suggests that many corporate tax departments

stepped-down preferred strategy. See I.R.S. Notice 97-21, 1997-1 C.B. 407 (describing deals where loans from foreign banks were treated as investments, purporting to give the taxpayer a deduction for principal paid). When the IRS issued the notice closing down the stepped down preferred shelter, analysts estimated that large corporations such as the Walt Disney Corporation, Dayton Hudson, Allied Signal and Freddie Mac had issued approximately $\$ 10$ billion of stepped down preferred stock. See Beck, supra note 36, at 108 .

41. An example is the now-famous statement by Michael Graetz. See supra note 1.

42. The development of derivatives figures in both accounting and tax gimmicks because of the flexibility they permit in manipulating cashflows and creating complex transactions for particular purposes. See, e.g., Frank Parnoy, A Revisionist View of Enron and the Sudden Death of "May," 48 VILL. L. REV. 1245 (2003) (asserting the importance of financial derivatives to the collapse of Enron); Alex Berenson, Report Says Freddie Mac Misled Investors, N.Y. TIMES, July 24, 2003, at Cl (reporting that Freddie Mac used a range of accounting gimmicks, including selling and repurchasing bonds to record loss and no longer reporting market prices for derivatives to avoid reporting gains).

43. This followed an earlier period in the 1970s and 1980s when tax shelters were marketed primarily to wealthy individuals. Those early shelters often involved partnerships that purchased an actual asset (farmland, racehorses, movie productions) at inflated prices using non-recourse debt, in order to generate artificial tax losses from high interest and depreciation deductions for partners with only nominal economic investments in the enterprise. Others attributed losses to taxpayers from passive activities (such as leases) to offset unrelated operating income from active businesses. Congress responded with the at-risk rules of I.R.C. $\S 465$ (2000) (limiting losses to economic investments at risk) and the passive activity loss rules of I.R.C. $\$ 469$ (2000) (requiring a taxpayer to track active and passive activity income and losses on separate schedules and restricting use of passive losses). The new provisions effectively ended the early individual shelters, but did not apply to large corporations. See generally Marvin S. Cash, The Application of the At-Risk Rules to Limited Liability Companies, 14 VA. TAX REV. 483, 488-89, 494-95 (1994) (discussing at-risk rules); David Wessel, Finding Ways to Thwart The American Art of Tax Sheltering, WALL ST. J., Mar. 6, 2003, at A2 (noting that prior to the 1986 reforms, as many as 90,000 cases "clogged the enforcement pipeline," but after the reforms, sheltering became "less lucrative"); Michael Oberst, The Passive Activity Provisions-A Tax Policy Blooper, 40 U. FLA. L. REV. 641 (1988) (arguing that the passive activity loss rules may remedy tax shelter use by wealthy taxpayers at a high cost, if at all, because of their broad reach); Robert J. Peroni, A Policy Critique of the Section 469 Passive Loss Rules, 62 So. CAL. L. REV. 1, 3-4 (1988) (suggesting that the passive activity rules achieve their goal of reducing individual tax shelter activity at a high cost from "economic inefficiency, inequity and complexity").

44. See, e.g., David Cay Johnston, Sham Shelters for Business Flourish as Scrutiny Fades, N.Y. TIMES, Dec. 19, 2000, at A1 (reporting that the shelter business changed when promoters "could create business deals that existed only on paper and could wipe out enormous tax bills" for "a cut of the savings"); Beck, supra note 
received "cold calls" from investment banks, accounting and law firms: news about a company's significant taxable transaction was an opportunity to offer a gain-sheltering artificial loss generator. ${ }^{45}$ Auditors, with deep knowledge of their clients' financial condition and of transactions that would materially affect their balance sheets, were in an especially advantageous position to use their tax expertise to offer tax services, including sales of existing proprietary transactions or development of customized structures, to eliminate tax gains. ${ }^{46}$

Although confidentiality of business deals and tax returns makes it impossible to verify the extent of revenue loss from abusive tax shelters, ${ }^{47}$ most commentators believe that significant reductions in effective tax rates, and the growing "credibility gap" between accounting income and taxable income over the last decade, ${ }^{48}$ stem in considerable part from corporations' participation in aggressive tax transactions. ${ }^{49}$ In its

36, at 110 (quoting Joseph Bankman's statement that early shelters "had to use real assets, like railroad cars or computers, which led to an inevitable level of business risk" but promoters can design corporate tax shelters "using financial instruments ... with very little nontax risk").

45. See, e.g., Lee A. Sheppard, Goodbye Mr. CHIPs: Lease Stripping on Trial Again, with Add-Ons, 100 TAX NOTES 453 (2003) (describing a deduction-generating lease-stripping tax shelter sold to EDS, Advanta, Interpublic Group and Rhone-Poulenc that also purported to generate an artificial basis for another shelter arranged with the Long Term Capital Management hedge fund, and indicating that Babcock \& Brown, the investment bank promoting the shelter, sought out and identified the corporate shelter customers before organizing the foreign intermediary needed to execute the lease-stripping shelter).

46. Joseph Bankman describes the influx of investment banks and accounting firms into the tax shelter market as follows:

A good deal of tax shelter activity is carried out by investment banks.... The remaining primary promoting group is comprised of the large accounting firms.... [A] ided by their close contact with corporate executives, and corporate tax departments in particular, accounting firms have been tremendously successful in penetrating the tax shelter market. Many, if not most, observers believe that accounting firms hold the lion's share of the market.... [M] any observers also believe that accounting firms are responsible for many of the most aggressive shelters.

New Market, supra note 40 , at 1780 .

47. There is insufficient information both because corporate tax returns are confidential and because the tax shelter problem is revealed at least as often by accidental discoveries and anonymous tipsters as by systematic IRS investigations of particular companies' returns. See, e.g., Sheryl Stratton, Privilege Sidelines Shelter Actions, Gov't Changes Tack, 100 TAX NOTES 295, 300 (2003) (reporting that BDO Seidman shelter activity investigation began on a tip).

48. Alan Murray, Political Capital: Esrey Story Shows Corporate Scandals Also Hurt Taxpayers, WALL ST. J., Feb. 11, 2003, at A4 (referring by "credibility gap" to the dramatic increase in the difference between income reported for book purposes as compared to that reported for tax purposes).

49. See, e.g., Mihir A. Desal, The Corporate Profit Base, Tax Sheltering activity, and the Changing Nature of EMPloyee Compensation (NBER Working Paper No. W8866, Mar. 2002) (concluding that the markedly increasing divergence between corporate book and tax income during the 1990s cannot be explained by the increase in deductions for stock option exercises or the increased levels of earnings management but rather likely reflects increased use of aggressive tax shelters); Martin A. Sullivan, News Analysis, Let the Good Times Roll: Options and Tax-Free Profits, 87 TAX NOTES 1185, 1185 (2000) (stating that the increased use of stock options as compensation only explains a portion of the decrease in corporate income tax paid); David Cay Johnston, Corporations' Taxes are Falling Even as Individuals' Burden Rises, N.Y. TIMEs, Feb. 20, 2000, at Al (attributing erosion of corporate tax revenues to aggressive corporate tax shelters); Corporate Tax Shelters, Statement before the House Ways and Means Committee, Nov. 10, 1999, 1999 WL 27596853 (testimony of Jonathan Talisman) (stating that "corporate tax shelters are designed to, and do, substantially reduce the corporate tax base" and suggesting that the data from the increasing gap between book and taxable income suggests that tax shelter activity is increasing); Bankman, supra note 40 , at 1776 
1999 study of abusive corporate tax shelters, the staff of the Joint Committee on Taxation concluded that "the use of corporate tax shelters has grown significantly in recent years." $" 50$ Because the largest corporations are disproportionately public companies, they are the most likely culprits in the tax shelter game. ${ }^{51}$

Treasury has reported "anecdotal evidence" that abusive corporate tax shelters reduce federal tax revenues by $\$ 10$ billion annually, at a minimum. ${ }^{52}$ Treasury's estimate of the cost of corporate tax shelters may be overly conservative, if any conclusions can be drawn from the decline in corporate income tax payments and effective tax rates. Corporate income tax revenues declined significantly over the last half-century as a proportion of the gross domestic product, from $4.18 \%$ in 1949 to barely more than $1.50 \%$ today, a $64 \%$ decline. $^{53}$ Robert S. McIntrye and T.D. Coo Nguyen report that corporations have shouldered a declining share of the income tax burden in the last decade, from around $21 \%$ of total taxes paid in 1994 to $17 \%$ in 2000 , based on reviews of income tax records of 250 public companies. ${ }^{54}$ The most recent statistics for fiscal year 2002 show that the share of federal taxes paid by corporations has declined further to $10.5 \% .55$

(asserting that a "sophisticated," "complex" and "aggressive" market for shelters "is growing at a breakneck speed"); TREASURY STUDY, supra note 35, at 11 (noting concerns about rampant growth of aggressive tax shelters expressed by the American Bar Association, the New York State Bar Association, and the Tax Executives Institute, among others); Janet Novack \& Laura Saunders, The Hustling of $X$ Rated Shelters, FORBES, Dec. 14, 1998, at 198, 203 (discussing the "thriving industry [of] hustling corporate tax shelters," including participation by major accounting firms). Dana Trier, a tax partner at prestigious law firm Davis Polk \& Wardwell, former Treasury official, and principal drafter of a 1999 New York State Bar Association report on tax shelters, notes that tax shelter problems have been around since the $1980 \mathrm{~s}$, but the problem "really started to show itself" in the mid-1990s, when it came on like a "snowball rolling downhill." Tamara Loomis, Tax Shelters; Treasury and the Tax Courts are Cracking Down, N.Y.L.J., Aug. 17, 2000, at 5 col. 2.

50. JCT PENALTY STUDY, supra note 35, at 2.

51. George K. Yin, Business Purpose, Economic Substance, and Corporate Tax Shelters: Getting Serious about Corporate Tax Shelters: Taking a Lesson From History, 54 SMU L. REV. 209, 228 (2001).

52. Pamela J. Gardiner \& Gordon C. Milbourn III, Management advisory Report: The Strategy for Curbing abusive Corporate Tax Shelter Growth Shows Promise but Could Be ENHANCED BY PERFORMANCE MEASURES, Ref. No. 2001-30-159 (Sept. 13, 2001), available at http://www.treas.gov/tigta/2001 reports/200130159fr.html (last visited Oct. 15, 2003). See also Mark L. Silow, IRS Stands to Get Aid in Tax Shelter Battle, 228 LEGAL INTELLIGENCER 5 (Feb. 18, 2003) (reporting GAO estimate of $\$ 25$ to $\$ 45$ billion of lost tax revenues annually from abusive tax schemes).

53. These percentages are based on government data on GDP and corporate tax receipts. See U.S. Department of Commerce, Bureau of Economic ANalysis, CuRrent-Dollar and "Real" Gross DOMESTIC PRODUCt (June 26, 2003), available at http://www.bea.gov/bea/dn/gdplev.xls (last visited Oct. 15, 2003) (BEA reports GDP, in current dollars, at $\$ 267.7$ billion in 1949 and $\$ 10,082.2$ billion in 2002); OFFICE

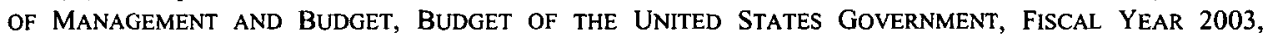
HISTORICAL TABLES, Table 2.1 (Jan. 20, 2001), available at http://www.whitehouse.gov/omb/budget/fy2003/ sheets/hist02zl .xls (last visited Oct. 15, 2003) (OMB reports corporate tax receipts of $\$ 11.192$ billion in 1949 and $\$ 151.075$ billion in 2001).

54. Robert S. McIntyre \& T.D. Coo Nguyen, Corporate Income Taxes in the 1990s (Inst. on Tax. and Econ. Pol'y, Oct. 2000) at 16, available at http://www.ctj.org (last visited Oct. 15, 2003). See also Tax Penalties and Interest, Statement before the S. Fin. Comm., 2000 WL 11069130 (Mar, 8, 2000) (statement of Kenneth J. Kies) (stating that corporate income taxes for fiscal 1999 were $10.1 \%$ of federal receipts).

55. See TABle I - Summary of INTERNAl REVENUE Collections, By TYPE OF TAX, Fiscal Years 2001 AND 2002, STATISTICS OF INCOME BULLETIN (May 2003), available at http://www.irs.gov/pub/irssoi/02db01 co.xls (last visited Oct. 15, 2003); David Cay Johnston, Tax Inquiries Fall as Cheating Increases, N.Y. TIMES, Apr. 14, 2003, at A16 (discussing recently released IRS data that "show a continuing shift of tax 
Although the maximum statutory tax rate on corporate income for the largest U.S. public corporations is $35 \%, 56$ many of those corporations have a substantially lower effective tax rate. They pay little or no taxes to the federal government, in spite of reporting healthy pre-tax profits in their financial statements. ${ }^{57}$ The McIntyre-Nguyen study found an overall effective corporate tax rate on the 250 largest public corporations of only $20.1 \%$ in 1998 , with many companies in the "zero-or-less tax club." 58 Other studies point to dramatic declines in the effective tax rate of particular public corporations over the last five years. ${ }^{59}$

The remainder of this Subpart focuses on the role of accounting firms in tax shelters. Section 1 overviews tax aspects of the Enron/Arthur Andersen debacle. Section 2 considers generally the role of accounting firms in tax shelters.

\section{Enron and Arthur Andersen Redux: Enron's Corporate Tax Shelters}

With the accounting spotlight on Enron and Arthur Andersen, Enron's tax shelters also captured attention. On February 13, 2003, the Joint Committee on Taxation staff

burdens away from businesses and onto individuals").

56. I.R.C. $\S 11(2002)$.

57. A part of the decline in corporate tax revenues undoubtedly stems from enhanced tax benefits (socalled "tax expenditures") explicitly provided in the tax laws. For example, provisions allowing companies to accelerate tax deductions for depreciation provided the "largest corporate tax break on the government's official list of 'tax expenditures'." McIntyre \& Nguyen, supra note 54, at 11. Deductions to corporations upon employee exercise of compensatory stock options also accounted for a substantial portion of the decline in effective tax rates over the 1996-98 period of the McIntyre-Nguyen study. Id. at 13. See also Irwin M. Stelzer, Big Business's Bad Behavior, WEEKLY STANDARD, July 22, 2002 (stating that the "expensing of options would reduce aggregate corporate profits by about 8 percent"), reprinted in 148 CONG. REC. S6764 (July 15, 2002); Martin A. Sullivan, News Analysis, Let the Good Times Roll: Options and Tax-Free Profits, 87 TAX NoteS 1185,1185 (2000) (stating that "the recent increase in the exercise of employee stock options appears to be a major reason for the decline in federal corporation income tax receipts that occurred in 1999 despite the simultaneous large increase in corporate profits"); Gil B. Manzon, Jr. \& George A. Plesko, The Relation Between Financial and Tax Reporting Measures of Income, 55 TAX L. REV. 175, 192 (2002) (stating that nonqualified stock option compensation has had a significant effect on corporate tax revenue and book-tax differences, and citing a Bear Stearns estimate that the tax benefit from stock options for the seven largest NASDAQ 100 corporations may exceed $10 \%$ of cash flow). These explicit tax expenditures do not account for a considerable portion of the decline in corporate profits, however. See generally DESAI, supra note 49 (concluding that increased compensation deductions from stock options have played a role in declining corporate taxes, but cannot account for a considerable portion of the decline).

58. McIntyre \& Nguyen, supra note 54 , at 7.

59. For example, in a study of companies in the S\&P 500 based on their financial statements, George Yin reports that "[o]f the 25 largest companies in the sample (based on their reported pre-tax book income over the six years [ 1995 through 2000]), Microsoft had the largest decline (18.74 percentage point decline from $22.35 \%$ ETR [effective tax rate] in 1995 to $3.61 \%$ ETR in 2000, an $83.9 \%$ decrease), followed by Verizon (17.22 points or a $42.2 \%$ decrease), and American International Group (15.40 points or a $52.7 \%$ decrease)." George Yin, How Much Tax Do Large Public Corporations Pay? Estimating the Effective Tax Rates of the S\&P 500, 89 VA. L. REV. 1790, 1797 (2003). Overall, Yin estimates that the average corporate effective tax rate declined by $16 \%$ between 1995 and 2000 , to $24.2 \%$. Id. Calvin Johnson's recent analysis of the implicit tax on municipal bonds, however, would support a conclusion that the average corporate effective tax rate declined substantially more than that, to $10 \%$ or even less. See Calvin H. Johnson, A Thermometer for the Tax System: The Overall Health of the Tax System as Measured by Implicit Tax, 56 SMU L. REV. 13, 13 (2003) (demonstrating significant erosion of the tax base by showing that the implicit tax rate on municipal bonds is "lower at times than the lowest statutory tax bracket of $10 \% ")$. 
presented to the Senate Finance Committee a detailed report of its investigation of Enron's federal tax and compensation issues. ${ }^{60}$ The JCT Report identified twelve complex tax-motivated transactions with which Enron reduced its tax bills and gained financial accounting benefits from 1995 to 2001 . These transactions were "espoused by outside counsel and monitored by outside accountants." ${ }^{161}$ In most cases, there was no independent assessment of the transactions, but rather an "incestuous relationship" between outside advisers and Enron. ${ }^{62}$ Over the six years from 1995 to 2001, Enron increased its reported earnings by $\$ 651$ million while saving $\$ 257$ million in federal income taxes, for fees of approximately $\$ 88$ million to advisers and promoters. ${ }^{63}$

The lack of a business purpose in most (if not all) of these transactions is striking. The Joint Committee on Taxation staff concluded that Enron's tax-motivated transactions had no business purpose other than the circular one of producing financial accounting revenue by reducing tax liabilities. ${ }^{64}$ The Enron bankruptcy examiner agreed:

The Tax Transactions had no business purpose other than to increase reported earnings .... Enron frequently acquired assets that it did not need and that were not part of its business operations, such as airplane leases and interests in mortgage loans, to take advantage of the application of GAAP [generally accepted accounting principles] for accounting for income taxes in combination with GAAP governing business acquisitions. ${ }^{65}$

In many of the deals, the tax opinion from the purportedly independent tax adviser explicitly indicated that the business purpose for the transaction, necessary for the intended tax benefits, was the creation of financial accounting revenues. ${ }^{66}$

Over that same period, Enron's tax department evolved into a profit-generating

60. See JCT REPORT, supra note 39. The JCT REPORT does not deal with all of Enron's strategies that may have been motivated solely to avoid U.S. federal income taxation. For example, Enron established a number of subsidiaries in tax haven countries including the Netherlands, Cayman Islands, and Bermuda and engaged in various tax-motivated hedging and derivatives transactions. See Peckron, supra note 17, at 864-65 (citing Enron's 2001 10K filing, available at http://www.sec.gov/Archives/edgar/data/72859/0000072859-97000009.txt (last visited Oct. 15, 2003)).

61. Peckron, supra note 17 , at 857 .

62. This strong phrase is used in the written testimony of the Joint Committee on Taxation staff in commenting on Enron's tendency to use advisers from a small pool: the advisor to Enron on one deal might well be the advisor to the promoter on another. See JoINT COMMITTEE ON TAXATION, WRITTEN TESTIMONY OF THE STAFF OF THE JOINT COMMITTEE ON TAXATION ON THE REPORT OF INVESTIGATION OF ENRON CORPORATION AND RELATEd ENTITIES REgaRdING FEDERAL TAX AND COMPENSATION IsSUES, ANd POLICY RECOMMENDATIONS (JCX-10-03), Feb. 13, 2003, at 10 [hereinafter ENRON TESTIMONY].

63. JCT REPORT, supra note 39 , at 9 . The bankruptcy examiner's report, based on slightly different data, puts the fees for tax transaction assistance to promoters and third party advisers at $\$ 73$ million. ENRON BANKRUPTCY REPORT, supra note 16 , at $88 \mathrm{n} .170$.

64. JCT REPORT, supra note 39, at 8 (stating that "[a]t their core, Enron's structured transactions were designed to permit Enron to take the position that its long-term tax benefits could be converted to current or short-term financial statement net income. In most of the structured transactions discussed in this Report, the origin of the financial accounting benefits was the reduction in Federal income tax that the transaction was anticipated to provide either currently or in the future.").

65. ENRON BANKRUPTCY REPORT, supra note 16 , at 40 .

66. See id. at $87 \mathrm{n} .168$ (stating that the firms of Akin, Gump, Strauss, Hauer \& Feld, LLP; McKee Nelson Ernst \& Young, LLP; and King \& Spaulding each delivered tax opinions that relied on a business purpose of increased financial statement revenues to justify the tax transaction). 
business center. ${ }^{67}$ The tax department's ability to work with a small coterie of accountants, lawyers and bankers to structure transactions that purported to comply with tax requirements became central to Enron's goals of simultaneously achieving tax savings and enhancing current financial statement revenues. ${ }^{68}$ The front-loaded accounting benefits from the longer-term tax transactions translated into a boost in current profits. ${ }^{69}$ That is, "[t]ransactions designed to duplicate losses (i.e., deduct the same tax loss twice) would be recorded on the financial statements as producing income (not loss)." 70 Enron's corporate tax planning group was apparently quite proud of its ability to increase Enron's reported profits in this way, claiming the department's efforts generated approximately $\$ 1$ billion in revenues over a five-year period. ${ }^{71}$

Arthur Andersen's role in Enron's tax planning is illustrative. Arthur Andersen was both promoter and tax opinion provider (as well as external auditor) for Tanya and Valor, two of Enron's earliest tax shelters that used essentially the same contingent liability device. ${ }^{72}$ They were designed to generate an artificial duplication of loss as follows: (1) high basis assets and unrelated contingent environmental liabilities would be transferred to an affiliated corporation in exchange for low value, high basis stock; (2) the stock would be sold to selected Enron employees to generate a capital loss; (3) later, the stock would be repurchased (at a tidy payoff to accommodating employees); and (4) Enron would benefit from a duplicate deduction of the loss from step (2) as payments were made on the contingent liabilities. When Tanya was implemented, it was discovered that Enron did not have appropriate environmental liabilities. Enron instead transferred a

67. See JCT REPORT, supra note 39, at 8 (noting that "[a]s Enron's management came to realize that taxmotivated transactions could generate financial accounting benefits, Enron looked to its tax department to devise large transactions that would increase its financial accounting income").

68. Id. at 8 .

69. Id. at 9. The bankruptcy examiner provides a concise description of the way "artificial transactions" can create tax deductions in future years that generate financial accounting income in current periods. See ENRON BANKRUPTCY REPORT, supra note 16, at 88-90. The mechanism is the recording of deferred tax assets or liabilities which take into account the estimated future tax effect attributable to timing differences between GAAP and taxable income or deductions. See id. at $90 \mathrm{n} .177$.

70. JCT REPORT, supra note 39 , at 8.

71. April Witt \& Peter Behr, Enron's Other Strategy: Taxes; Internal Papers Reveal How Complex Deals Boosted Profits by $\$ 1$ Billion, WASH. POST, May 21, 2002, at A1, quoted in ENRON BANKRUPTCY REPORT, supra note 16, at 87 n.169. The Enron bankruptcy examiner notes an insider's report that the tax transactions were habit-forming: "kind of like cocaine-they got kind of hooked on it." ENRON BANKRUPTCY REPORT, supra note 16, at 87 n. 169 (quoting Robert J. Hermann, former Vice-President, Tax, Enron Corp., in an Aug. 8, 2002 interview with Philip C. Cook).

72. JCT REPORT, supra note 39 , at 10 , Table 3 . The IRS published a notice identifying the contingent liability shelter as a listed transaction in early 2001. See I.R.S. Notice 2001-17, 2001-01 C.B. 730 (Feb. 26, 2001) (indicating that losses from these transactions would be disallowed under one of a number of theories, including among others: failure to satisfy the economic substance doctrine; failure to satisfy the non-recognition requirements for a $\S 351$ transaction because of a lack of business purpose or lack of transfer of a property interest; application of the corporate acquisition anti-avoidance rule in $\S 269$; or application of $\S 357$ (b) gain recognition). A settlement initiative was announced in October 2002. Rev. Proc. 2002-67, 2002-43 I.R.B. 733 (2002). The enactment of Section 358(h) effectively ended this shelter in most cases. See I.R.C. $\$ 358(\mathrm{~h})$ (West 2004) (reducing basis to fair market value where a liability is assumed by another person to the exchange). The IRS recently issued temporary and proposed regulations to prevent evasion of Section 358 (h) by using a partnership nonrecognition transaction to duplicate losses on the partnership's assumption of a partner's liability. See T.D. 9062, 2003-28 I.R.B. 46. See also Lee A. Sheppard, News Analysis: Enron's Contingent Liability Shelter, 98 TAX NOTES 1302, 1304-06 (2003) (discussing Tanya and Valor). 
portion of its pension liabilities and sold the new stock to a small number of its human resources employees. That change, also used in Valor, created a post hoc colorable business purpose, in that Enron claimed to undertake the loss-producing transaction to provide an incentive to some human resource personnel to work harder overseeing pension assets. ${ }^{73}$

These two early Andersen-designed shelters are only illustrative of the types of activities in which Enron engaged. ${ }^{74}$ Although Arthur Andersen did not design and promote all of Enron's tax-motivated transactions, it approved the accounting and thus indirectly certified the purported tax benefits claimed. The firm benefited handsomely from its tax work for Enron: its audit, consulting and tax work earned fees of $\$ 46.8$ million for fiscal year 1999, $\$ 58$ million for fiscal year 2000, and more than $\$ 50$ million for fiscal year 2001. ${ }^{75}$ Not surprisingly, the Joint Committee of Taxation staff report reveals a pattern of going along with those at Enron who pushed the limits of accounting and tax rules in order to achieve announced revenue targets. ${ }^{76}$ The bankruptcy examiner also registered his strong disagreement with Enron's "egregious" "manipulation"77 and "aggressive interpretations" of tax rules. ${ }^{78}$

\section{Other Auditors' Tax Shelter Transactions}

Major accounting firms other than Arthur Andersen have been increasingly involved in designing and promoting shelter transactions for wealthy individual and corporate clients, including audited companies and their managers and directors. ${ }^{79}$ Accounting

73. See JCT REPORT, supra note 39 , at 118-23 (describing project Tanya). The idea that a corporation would intentionally lose millions of dollars in a transaction designed primarily to inspire a few of its employees merely to perform their jobs of ensuring that pension assets not lose money is, of course, ludicrous on its face.

74. Even more inventive were Enron's REMIC shelters, where phantom income was directed to foreign shareholders while the deferred tax benefit from the loss on REMIC residuals was recast as a current accounting gain. See JCT REPORT, supra note 39, at B182-B198, B214-B242 (Enron documents from Bankers Trust and Arthur Andersen describing REMIC residual transaction). See also Lee A. Sheppard, News Analysis, Enron's REMIC Deals: Tax Shelter or Attractive Nuisance?, 98 TAX NOTES 1488 (2003) (discussing use of REMICs as shelter). Enron also used FASITs. See Lee A. Sheppard, News Analysis, Enron Abused FASITs, While No One Else Uses Them, 98 TAX NOTES 1794 (2003) (discussing Cherokee and Sequoia deals to produce large interest deductions).

75. See Peckron, supra note 17 , at 906 ; see also Jennings, supra note 18 , at $214-18$ (indicating that conflicts of interest "consumed" Enron's accommodating auditors, as shown by payments to Andersen of $\$ 25$ million for audit work and $\$ 27$ million for tax and other consulting services).

76. The Enron report is replete with evidence of the pervasive influence of earnings targets. For example, the report points out that Enron's CEO Kenneth Lay announced a $\$ 1$ billion revenue target for 2000 at least as early as January 1997. See ENRON TESTIMONY, supra note 62, at 9 n.7 (citing a Jan. 21, 1997 Enron release, available at http://www.enron.com/corp/pressroom/releases/1997/12per.html (last visited Oct. 15, 2003)).

77. ENRON BANKRUPTCY REPORT, supra note 16 , at 88 . In one basis step-up transaction described by the examiner, "Enron recorded an aggregate increase in after-tax net income of $\$ 460$ million . . . even though it did not deduct a single dollar of increased depreciation from any of the designated assets." $I d$. at 92.

78. Id. at 93. These transactions were so aggressive that the head of the tax department said that "the word on the street was if Enron wasn't interested, no one would be and you might as well throw it in the can." Id. at 93 n.182 (quoting Robert J. Hermann, former Vice-President, Tax, Enron Corp., in an Aug. 8, 2002 interview with Philip C. Cook).

79. See, e.g., John D. McKinnon \& John Harwood, Tax Shelters Come Under Fire, WaLl ST. J., June 6, 2003 , at A4 (reporting Treasury study showing that donation of patents at inflated valuations is being widely marketed by accounting firms). 
firms now commonly offer sophisticated transactional tax planning traditionally reserved to legal firms, an expansion of scope that increased when accounting firms began hiring experienced tax lawyers. ${ }^{80}$

The expansion into multidisciplinary tax practice went hand in hand with aggressive marketing techniques that often reaped unusually large fees through "value pricing." 81 Deloitte established a sales group, known informally as the Predator group, to offer tax ideas to wealthy clients. ${ }^{82}$ More than half of BDO Seidman's tax revenue in 2000 came from an aggressive tax services team known informally as the wolf pack. ${ }^{83}$ Similarly, a former KPMG tax partner reported increasingly heavy pressure to sell tax services. ${ }^{84}$ KPMG marketed a shelter ${ }^{85}$ to as many as 160 clients (primarily individuals), ${ }^{86}$ with claims that the shelter was "bullet proof" because it "uses the IRS's own laws against them." 87 In 1999, Ernst \& Young formed a captive law firm specializing in tax practice, McKee Nelson Ernst \& Young, receiving applause for its innovativeness and criticism for its multidisciplinary practice. ${ }^{88}$ After Ernst \& Young was criticized for its aggressive sales of tax shelters to wealthy individuals, it stopped that sales focus. ${ }^{89}$ It continued its

80. Frank J. Gould, Giving Tax Advice-Some Ethical, Professional, and Legal Considerations, 97 TAX NOTES 523, 538 (2002).

81. See, e.g., Johnston, supra note 44 (noting that shelters took off after accountants began charging for tax services by setting their fees as a percentage of taxes saved or, more widely accepted, by "value pricing" the services based "on how much a client would be willing to pay to save a lot more on taxes").

82. Cassell Bryan-Low, Unhappy Returns: Accounting Firms Face Backlash Over the Tax Shelters They Sold, WALL ST. J., Feb. 7, 2003, at A1.

83. Id. (indicating more than $\$ 100$ million of tax sales revenues to the team in 2000 , according to legal filings).

84. Id. (quoting Donald M. Griswold as stating that the push to sell "became a monster that needed to be fed").

85. See Jacoboni Complaint, supra note 40 (describing the foreign leveraged investment program and offshore portfolio investment strategy known as "FLIP" and OPIS"). The transaction required the tax shelter participant to purchase shares in an accommodation party and shares in a foreign corporation. The accommodation party also owned shares in the foreign corporation. Promoters claimed that the accommodation party's redemption of its shares in the foreign corporation should be treated as a dividend, basis in those shares should shift to the participant under section 302, and the participant should have a capital loss on its sale of the foreign corporation's shares. See I.R.S. Notice 2001-45, 2001-2 C.B. 129 (2001) (current regulations require "proper adjustment" of basis to take account of a dividend redemption). The IRS has since issued proposed regulations that suspend the basis loss and do not permit the basis to be shifted to another party to whom ownership of the redeemed shares could be attributed. See REG-150313-01, 67 Fed. Reg. 64,331 (Oct. 18, 2002) (to be codified at 26 C.F.R. pt. 1) (proposing new Treas. Reg. $\S \S 1.302-5$ and 1.302-6 and amendments to Treas. Reg. $\S 1.302-2$, among other changes). The IRS also undertook a settlement program for these basisshifting shelters, whereby the participant conceded $80 \%$ of the tax benefit and $80 \%$ of the deduction for the transaction costs and agreed to capitalize the remaining $20 \%$ of the transaction costs. I.R.S. Ann. 2002-97, 2002-43 I.R.B. 757 (providing waiver of penalties if transaction was disclosed). See also Lee A. Sheppard, Viewpoints, Where Are We Going With Tax Shelter Settlements, 97 TAX NOTES 417, 418 (2002) (discussing settlements).

86. Jacoboni Complaint, supra note 40, at \30 (quoting Halpert Declaration at I 37(a), submitted in connection with the IRS's case to enforce summonses against KPMG). See also United States v. KPMG LLP, 237 F. Supp. 2d 35 (D.D.C. 2002) (ordering KPMG to provide entire privilege log to Special Master for review).

87. Jacoboni Complaint, supra note 40 , at 910.

88. See Bryan-Low, supra note 28 and accompanying text.

89. Id. See also Cassell Bryan-Low \& John D. McKinnon, Tax Shelter Sellers Lie Low for Now, Wait Out Storm: Accountants Rename Strategies, Cut Staff, but Once Stocks Rise, A Weak IRS is Very Tempting, WALL 
corporate tax sales, however, claiming that customized corporate strategies were not problematic. ${ }^{90}$

Investigations and lawsuits by disgruntled taxpayers, shareholders, and the IRS over tax services provided by major accounting firms provide further evidence of the overall shelter problem. For example, various clients sued KPMG over sales to them of the shelter that was the subject of the Jacoboni Complaint, ${ }^{91}$ and the IRS issued nine different summonses against KPMG for information connected with that and other KPMG tax shelters. ${ }^{92}$ KPMG claimed accountant-client privilege ${ }^{93}$ and insisted that its tax advice was appropriate. ${ }^{94}$ The IRS' review of tax shelter reporting and list keeping requirements also led to more than 75 summonses against other accounting and law firms, including BDO Seidman and Arthur Andersen, with at least five cases going to the Justice Department for enforcement. ${ }^{95}$ Ernst \& Young received summonses regarding a proprietary currency option strategy for creating an artificial loss. ${ }^{96}$ More recently,

ST. J., Feb. 14, 2003, at C1 (reporting disbandment of teams called "The Tempest" and "Othello").

90. See Bryan-Low, supra note 28.

91. See, e.g., David Cay Johnston, Wealthy Suing Accountants Over Rejected Tar Shelters, N.Y. TIMES, Feb. 7, 2003, available at http://www.nytimes.com/2003/02/07/business/07SHEL.htm (last visited Oct. 15, 2003) (discussing a Coleman family suit in connection with the family's use of the KPMG FLIP/OPIS shelter to offset gains from the sale of the Asheville Mall and KPMG's advice to disregard the I.R.S. rules requiring registration of tax shelters); Jacoboni Complaint, supra note 40, at 130 (referring to $160 \mathrm{KPMG}$ clients for the FLIP/OPIS strategy); id. at I 45 (listing various participants in the FLIP/OPIS shelter); Sheryl Stratton, Seattle Shelter Investor Sues KPMG and Brown \& Wood, 99 TAX NOTES 1592 (2003) (reporting suit related to BLIPS transaction). The SEC has also launched an informal inquiry into the relation between Wachovia Corporation and KPMG, because of Wachovia's referrals of wealthy clients with recent capital gains sales to KPMG for tax shelter advice, at a time when KPMG earned more than triple the amount from providing tax and other consulting to Wachovia than from audit services. Cassell Bryan-Low \& Carrick Mollenkamp, Wachovia, KPMG Face SEC Probe Over Referrals, WALL ST. J., Aug. 15, 2003, at A3.

92. See, e.g., David Lupi-Sher, IRS Moves Aggressively Against Accounting Firms Marketing Tax Shelters, 2002 TNT 133-4 (July 11, 2002) (discussing IRS suits against KPMG and BDO Seidman in connection with summonses for information on tax shelters). For further discussion of KPMG's tax shelter

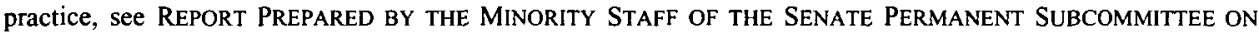
Governmental AfFaIRS, U.S. Tax Shelter Industry: The Role of Accountants, Lawyers, and Financial Professionals Four KPMG Case Studies: FLIP, OPIS, BLIPS, and SC2 (S. Prt. 108-34, 90-655 PDF, 2003) [hereinafter KMPG REPORT].

93. See Special Master Recommends that KPMG Disclose Most Documents in Tax Shelter Promotion Inquiry, 2003 TNT 52-18 (Mar. 18, 2003) (special master's January 24, 2003 report on remand from United States v. KPMG LLP, 237 F. Supp. 2d 35 (D.D.C. 2002), finding that most of the documents should be disclosed to the IRS).

94. See Johnston, supra note 91.

95. See Sheryl Stratton, Chief Counsel Sees Work on Guidance and Shelters Pay Off, 2003 TNT 47-2 (Mar. 11, 2003) (reporting comments of former IRS Chief Counsel B. John Williams Jr.); Cassell Bryan-Low, Court Rules Tax-Shelter Clients Lack Privilege of Confidentiality, WALL ST. J., July 24, 2003, at C9 (discussing suits by the Justice Department and taxpayers against advisers); United States v. BDO Seidman, 337 F.3d 802 (7th Cir. 2003) (finding that a taxpayer has no expectation of confidentiality in communications regarding transactions that must be disclosed under the tax law, so there is no privilege to protect firm's clients' identities from IRS); United States v. Arthur Andersen, LLP, No. 02-C-6790, 2003-2 USTC I 50624 (N.D. III., Aug. 15, 2003) (relying on Seventh Circuit's holding in BDO Seidman case to rule that Andersen must reveal its shelter clients' identities to the IRS).

96. The COBRA (currency options bring reward alternatives) strategy created an artificial loss to offset an unrelated capital gain through simultaneous purchases and sales of offsetting long and short currency options with the payment of a small net premium for the long options, transfers of the options and other securities held 
questions have been raised about KPMG's tax advice to HealthSouth, which faked profits of at least $\$ 1.4$ billion. ${ }^{97}$

Ernst \& Young also garnered attention in early 2003 when its sale of compensatory option tax shelters to Sprint's CEO and president resulted in the two executives' dismissal. ${ }^{98}$ The proprietary tax shelters purported to translate compensation income into capital gain using a contingent deferred payment swap. The shelters then eliminated the capital gain by manipulating a tiered partnership structure's sales of offsetting currency option gain and loss positions to produce an artificial loss. ${ }^{99}$ Informed of an IRS release that challenged similar option transactions, the Sprint board of directors declined to reverse the options. ${ }^{100}$ Since serving both Sprint and its executives created conflicts for Ernst, Sprint ultimately dismissed the executives in late 2002.101 Their removal and the

long term to a partnership formed for this purpose, termination of the partnership by transfer of the partnership interests to an $\mathrm{S}$ corporation formed for this purpose, and sale of the assets by the $\mathrm{S}$ corporation at a claimed loss because of failure to reduce the partners' bases in the partnership interests under $\S 752$ by reason of the partnership's assumption of the liabilities. Camferdam Complaint ๆ 55, Camferdam v. Emst \& Young International Inc., No. 02-cv-10100 97/6, 55 (S.D.N.Y. Dec. 20, 2002), available at http://pubs.bna.com/ip/ BNA/txc.nsf/837911 c53cc9d29185256498006894bf/aefa0543ee08264085256cc700068866? OpenDocument\& Highlight=0, CAMFERDAM (last visited Feb. 27, 2004) [hereinafter Camferdam Complaint]. See also I.R.S. Notice 2000-44, 2000-2 C.B. 255 (disallowing loss from such a strategy); Lee A. Sheppard, Government Shuts Down PICO Shelter and its Progeny, 97 TAX NOTES 31 (Oct. 7, 2002), 2002 TNT 196-11 (discussing this and similar shelters). The IRS announced plans to litigate another shelter strategy used by wealthy individuals to defer taxes on stock option grants by purportedly transferring the options to related parties for an installment note. See I.R.S. Notice 2003-47, 2003-30 I.R.B. 132 (July 28, 2003); John D. McKinnon \& Cassell Bryan-Low, IRS Targets Shelter for Stock Options, WALL ST. J., July 2, 2003, at A3 (providing background on corporations' responses to stock option shelters).

97. See Carrick Mollenkamp et al., Probe of HealthSouth Grows, Includes KPMG, WALL ST. J., Apr. 28, 2003 , at A6 (reporting that investigation of an accounting overstatement of $\$ 2.5$ billion has expanded to questions about tax transactions); Carrick Mollenkamp, Two More HealthSouth Officials Plead Guilty in Fraud Inquiry, WALL ST. J., Aug. 1, 2003, at C7 (indicating that HealthSouth scandal included tax fraud after discovery that company provided false tax information to conceal fictitious assets); Bloomberg News, HealthSouth Executive Admits to Falsifying Taxes, N.Y. TIMES, Aug. 28, 2003, at C7 (reporting tax executive's guilty plea to falsifying tax returns).

98. See Beale, supra note 34 , at 12-14 (providing a detailed description of the circumstances of the executives' ouster).

99. See id. at 12-13 (providing a more detailed description and tax analysis of the shelter); Rebecca Blumenstein \& Ken Brown, How the Sprint Tax Shelter Worked, WALL ST. J., Feb. 7, 2003, at A3 (description of shelter). IRS Notices 2002-35 and 2002-50 treat the separate parts of this strategy as a "listed transaction" for purposes of Section 6112. See I.R.S. Notice 2002-35, 2002-1 C.B. 992 (contingent payment swap shelter); I.R.S. Notice 2002-50, 2002-2 C.B. 98 (sales of currency options through tiered partnerships). The two executives claimed to avoid approximately $\$ 123$ million in taxes. Alan Murray, Political Capital, Esrey Story Shows Corporate Scandals Also Hurt Taxpayers, Wall ST. J., Feb. 11, 2003, at A4. On Emst \& Young's advice, they also avoided any withholding by claiming hundreds of thousands of personal exemptions. See Ruth Simon, Are You Taking Too Many Exemptions? Over 10, Think Again, WALL ST. J., Feb. 11, 2003, at D1.

100. Reversal would have been costly: Sprint would have lost its 2000 compensation tax deduction and would have had lower financial statement earnings because of expensing the replacement options. See Rebecca Blumenstein \& Carol Hymowitz, Troubling Options: Inside the Tough Call at Sprint: Fire Auditor or Top Executives?, WaLl ST. J., Feb. 10, 2003, at A1; Elliot Blair Smith, Tax Debt Piled Up for Sprint Execs, USA TODAY, Feb. 7, 2003, available at http://www.usatoday.com/money/industries/retail/2003-02-07-esrey_x.htm (last visited Oct. 15, 2003) (stating that Sprint received a $\$ 148$ million tax benefit from stock compensation in 2000).

101. Blumenstein \& Hymowitz, supra note 100; Carol Hymowitz, In the Lead: Sprint Case Shows New Risk to CEOs When Things Go Bad, WALL ST. J., Feb. 11, 2003, at A17. 
consequent disclosure of Sprint's requirement that its executives use its auditor for personal tax planning led to shareholder lawsuits against Sprint, the two executives, and Ernst. The Sprint case demonstrates the importance of such consulting fees to auditors. Ernst earned more than $\$ 65$ million from Sprint in consulting and audit fees in 2000 (when the option shelters were initiated), with regular audit fees accounting for only $\$ 2.5$ million of the total. 102

Accounting firms also developed stock compensation tax shelter strategies for the executives' corporations. These strategies could be marketed to corporations granting compensatory options at the same time that the firms marketed a compensatory option strategy to corporate executives. The corporate shelter purported to create an artificial capital loss that duplicated the compensation deduction. ${ }^{103}$

\section{B. Harms Caused}

Corporate, and corporate executive, participation in abusive tax shelter transactions can result in significant economic costs and market distortions. If a transaction is discovered on audit, companies will likely spend considerable sums for legal and accounting assistance in defending the strategy. At some point, a decision will have to be made to settle or contest the assessed tax liability. ${ }^{104}$ Settlement may entail interest and penalties in addition to taxes. ${ }^{105}$ Although small settlements are not likely to lead to further financial problems, a substantial tax claim and related interest and penalties could impact liquidity and debt servicing costs. Payment of tax liabilities can lead to earnings restatements, compounding the problem. ${ }^{106}$ On the other hand, companies that contest

102. Smith, supra note 100 .

103. See I.R.S. Notice 2000-60, 2000-2 C.B. 568 (Dec. 4, 2000) (describing the shelter and identifying it as a "listed transaction" for purposes of the $\S 6011$ regulations); Field Service Advice 200117020 (Jan. 24, 2001) (analyzing the tax consequences and the bases for denying the purported tax benefits). The gist of the shelter is as follows:

The parent corporation in a parent-subsidiary group contributes its stock to a subsidiary. The subsidiary then uses the stock to fund the parent corporation's employee pension obligations. Promoters claimed that the parent corporation should treat the transfer of parent stock by the subsidiary as a capital contribution to the parent. If that were the appropriate characterization, the parent corporation's basis in the subsidiary stock would exceed the stock's value, permitting the parent to claim a loss on sale on the stock. The correct characterization of the payment of the parent's pension obligation by the subsidiary is as a distribution by the subsidiary that reduces the Id. parent's basis in the subsidiary stock.

104. See, e.g., IRS Chief Counsel B. John Williams, Address to the Chicago Bar Association's Federal Taxation Committee Titled "Resolving Tax Shelters: By Settlement or Litigation" (Feb. 25, 2003) (indicating that the IRS and Treasury intend to strengthen enforcement efforts through summonses, focused examinations and targeted litigation), available at http://pubs.bna.com/ip/BNA/txc.nsf/493656f29562abd3 (last visited Feb. 19, 2004).

105. Various penalty and interest provisions may apply. See, e.g., I.R.C. $\S 6662$ (West 2004) (various accuracy-related and fraud penalties); $\S 6601$ (West 2004) (interest on underpayment); $\$ 6652$ (West 2004) (failure to file information statements). Settlement initiatives in 2002 were generous because of IRS backlogs. See, e.g., I.R.S. Ann. 2002-97, 2002-43 I.R.B. 757 (offering settlement of certain basis shifting transactions in which taxpayer concedes $80 \%$ of the tax liability as well as deduction of transactions costs and IRS concedes accuracy-related penalties in cases that are appropriately disclosed).

106. See, e.g., Nick Baker, ImClone Results Will Be Restated For Tax Liability, WALL ST. J., Apr. 1, 2003, 
tax deficiencies may become embroiled in litigation that extends over years or decades. ${ }^{107}$ Focus on litigation distracts managers from ongoing business activities. ${ }^{108}$

Aggressive corporations, like Enron, may allocate increasingly larger and more significant portions of their management, personnel, systems, and other resources to developing and continuing aggressive tax transactions that have no social value. Taxmotivated transactions may grow so large that they displace some part of a company's traditional operating business. A corporate culture that condones participation in tax shelters may lead to a company-wide decline in standards, whether in respect of accounting irregularities that tend to enhance manager compensation or cost cutting undertaken merely to demonstrate that a manager is taking control. That is, abusive tax transactions carry both a carrot-increased after-tax corporate income-and a stickdecreased efficiency because of loss of internal controls. ${ }^{109}$

The economic and other costs to the United States of abusive tax transactions are also significant. ${ }^{110}$ The ability of large corporations to make use of tax shelters undermines the voluntary compliance at the center of our tax system. ${ }^{111}$ The loss of corporate tax revenues increases regressivity through greater reliance on payroll and other taxes collected through withholding at the source. ${ }^{12}$

\section{CAusative Factors}

This Part compares tax compliance problems to the accounting scandals and concludes that they stem from similar underlying causes. Underenforcement creates the opportunity; earnings targets create the demand. Those factors combine with lucrative fees to create a burgeoning tax shelter industry with auditors (and lawyers) at the center.

at A6 (anticipating that ImClone Systems Inc. would have to restate its prior financial results by approximately \$24 million, excluding the impact of payments for interest and penalties, because of its liability for federal income taxes not withheld by the company or paid by its former chief executive, Samuel Waksal, on the exercise of certain stock options); Nick Baker, ImClone Systems, Inc. Loss of \$39.4 Million Is Posted; Tax Liability Is Major Factor, WALL ST. J., June 24, 2003, at A6 (reporting that ImCone's delayed 2002 balance sheet reflected a $\$ 38.8$ million tax liability).

107. See, e.g., UPS, Inc. v. Comm'r, 254 F.3d 1014 (11th Cir. 2001) (2001 appellate decision dealing with corporation's 1984 taxable year deficiencies, in litigation initiated in the Tax Court in 1995 and decided by the Tax Court in 1999), rev'g T.C.M. 1999-268 (CCH) (holding that transfer of profits to a shareholder-controlled reinsurance subsidiary was a sham).

108. Inefficiencies are a natural outgrowth of overly aggressive tax and accounting strategies, reflecting internal disagreements about appropriateness of the strategies. See, e.g., Glenn R. Simpson \& Sally Beatty, Dismissal Letters in Levi's Firings Raise Questions, WALL ST. J., June 17, 2003, A3 (discussing suits related to dismissal of Levi lawyer and accountant after they questioned aggressive tax and accounting strategies).

109. See, e.g., Kong-Pin Chen \& C.Y. Cyrus Chu, Internal Control vs Extemal Manipulation: A Model of Corporate Income Tax Evasion 3 (Dec. 17, 2002), available at $\mathrm{http}: / / \mathrm{ssrn}$.com/abstract $=353860$ (last visited Oct 15,2003 ) (contrasting corporate with individual tax evasion, and arguing that corporate tax evasion bears an efficiency cost-loss of internal controls-that may outweigh expected gain from tax evasion).

110. See Gardiner \& Milboum, supra note 52 and accompanying text (loss to the federal fisc).

111. See, e.g., Gardiner \& Milbourn, supra note 52 (noting the concern "that abusive corporate tax shelters could ultimately undermine voluntary compliance by reducing the trust responsible taxpayers have in the integrity of the tax system.").

112. Joseph H. Guttentag, Key Issues and Options in International Taxation: Taxation in an Interdependent World 4-5 (2001 Tax Conference, ADB Institute, Tokyo (Sept. 5, 2001)), available at http://www.adb.org/ Documents/Events/2001/Tax_Conference/sp_guttentag.pdf (last visited Oct. 15, 2003). 
Like accounting malfeasance, shelter proliferation results from an increased willingness of gatekeepers - in particular, the major accounting firms-to create and structure potentially abusive tax-saving strategies that boost corporate earnings. ${ }^{113}$ Although tax planning is a legitimate activity, within bounds, major accounting firms have promoted tax-avoidance schemes that have no genuine economic connection to the taxpayer's business. The strategies purport to succeed by depending on a mechanistic interpretation that does not comport with the underlying purpose of the applicable tax provision. ${ }^{114}$ Auditors should be "watchdogs" that expose the tax risk associated with these aggressive transactions to the corporate boards, shareholders and potential investors through their determinations of tax accruals and explanatory footnotes. Instead, they have been instrumental in pursuing their share of the high fees to be earned from helping clients to circumvent the tax rules.

\section{A. Underenforcement}

Like the SEC, the IRS has been underfunded and understaffed for some time. Its discovery methods, enforcement and sanctions have not kept pace with abusive tax transactions. ${ }^{115}$ The IRS has low audit rates, outgunned personnel, and limited resources for carrying cases through appellate litigation. ${ }^{116}$ In spite of a renewed commitment to target corporate tax shelters for litigation, the IRS initiated fewer tax investigations in 2002 than in prior years-a decline of 37 percent from 1992. ${ }^{117}$ At the same time,

113. See, e.g., Calvin Johnson, Special Reports, Corporate Tax Shelters, 1997 and 1998, 80 TAX NotES 1603,1606 (1998) (stating that "[t]he investment bankers and Big Five accounting firms are pushing corporate tax planning competitively to the very edge").

114. See JCT PENALTY STUDY, supra note 35, at 224 ("[T]he modern corporate tax shelter typically has an apparent foundation in the tax law. By taking advantage of 'glitches,' or the juxtaposition of unrelated Code provisions, these transactions are designed to 'work."'). See also supra note 36 and accompanying text (discussing the difficulty of defining abusive shelters). Judge Learned Hand famously stated that "[a]nyone may so arrange his affairs that his taxes shall be as low as possible." Helvering v. Gregory, 69 F.2d 809, 810 (2d Cir. 1934), aff $d$ in 293 U.S. 465 (1935). Regrettably, Hand's statement (taken out of context from the landmark opinion that established the economic substance doctrine for disallowing a tax benefit purported to be derived from a sham transaction) has provided succor to major tax shelter promoters who interpret it as a license to circumvent rules on the claim of assisting taxpayers in so arranging their affairs.

115. As then Treasury Deputy Secretary Stuart Eizenstat remarked in March, 2000:

[T] he ad hoc approach of past years, in which Congress or the Administration took action to close specific shelters as they came to our attention, was simply not working. We were outgunned and outmanned by tax shelter merchants. We were told that for each shelter we took action against, ten more were escaping without our notice. The situation was, and is, just like that of the mythical Hydra, except recast in the context of modern corporate finance. We were losing the battle for the integrity of our system of corporate taxation, and preservation of the corporate tax base.

Stuart E. Eizenstat, Remarks to the Tax Executives Institute MidYear Conference, Washington, D.C., LS-476 (Mar. 20, 2000) available at http://www.treas.gov/press/releases/ls476.htm (last visited Oct. 15, 2003). See also Tax Policy: Tax Policy Expert Calls Fraud 'Epidemic,' Urges Increased IRS Enforcement Efforts, DAIL Y TAX REP. (BNA), July 10, 2003, G6-G7 (quoting Urban Institute Senior Fellow Leonard Burman's statement that fewer than $1 \%$ of corporations are audited in spite of "a well publicized epidemic of questionable and illegal corporate tax shelters") [hereinafter Tax Policy].

116. See Johnson, supra note 113, at 1605; David Cay Johnston, I.R.S. Takes Aim at Big Shelters and Hopes Message Filters Down, N.Y. TIMES, July 6, 2003, at Al (quoting John Tigue Jr., a tax defense lawyer, as saying that the IRS "just do[es] not have the manpower to really do the job"); Tax Policy, supra note 115.

117. See ENForCEMENT Statistics-Criminal InVESTIGATION ENFORCEMENT STRATEGY, IRS (May 20, 
prosecutions for tax crimes declined to half the number prosecuted in $1992 .{ }^{118}$ The difficulties caused by the IRS's limited enforcement budget led former IRS commissioner Charles Rossotti to warn that tax practitioners sell tax strategies "on the simple premise [that] they can get away with it."119

\section{B. Tax Departments as Business Centers}

Large corporations have developed corporate cultures that exert enormous demands on executives to achieve revenue targets. ${ }^{120}$ As in accounting scandals, the increasingly common tendency of corporate managers to view internal finance and tax departments as just another means of meeting those targets fuels tax shelter growth. ${ }^{121} \mathrm{~A}$ corporate climate that applauds the use of corporate resources to pursue extraneous financial transactions that circumvent tax rules pressures tax professionals to "go along to get along." When managers face pressures to keep revenues and stock values inordinately high, fissures in ethics are bound to develop. ${ }^{122}$ Corporate tax departments are pushed to work more cooperatively with senior management to synchronize their results with operational targets, tune out ethical concerns and lean toward decisions that favor the bottom line. ${ }^{123}$ This profit-center role means they cannot act as a brake on the inherent tendency of the corporate enterprise to paint rosy pictures for the constituents who care most about profits-directors, shareholders and potential investors. Indeed, Enron's tax department saw itself as a team player in the profit-making game. ${ }^{124}$ As Joint Committee

2003), available at $\mathrm{http}: / \mathrm{www} . i r s . g o v / \mathrm{irs} /$ article$/ 0, \mathrm{id}=108792,00 \mathrm{html}$ (last visited Oct. 10, 2003). See also David Cay Johnston, Tax Inquiries Fall as Cheating Increases, N.Y. TIMES, Apr. 14, 2003, at A16 (discussing statistics); Amy Hamilton, IRS Refutes Figures Showing Less Prosecution of Tax Cheats, 99 TAX NOTES 311 (2003) (reporting on disagreement between the IRS and TRAC, a Syracuse University database, regarding criminal enforcement of tax laws and TRAC's claim that enforcement has declined sharply from a decade ago).

118. See ENFORCEMENT STATISTICS, supra note 117.

119. Thomas A. Fogarty, Esrey Expects No Penalty for Tax Shelter, USA TODAY, Feb. 7, 2003, available at http://www.usatoday.com/money/industries/telecom/2003-02-07-esrey-penalty_x.htm (last visited Oct. 15, 2003).

120. See, e.g., Deborah Ball \& Almar Latour, Ahold's Past Faces Scrutiny: Investors May Not Have Received Full and Timely Disclosure, WALL ST. J., Mar. 17, 2003, at B3 (noting that Ahold insiders "say there was a culture that pressured managers to achieve profit targets that eventually proved unrealistic. 'Ahold people were on the expansion track and simply did not want to hear certain warnings."').

121. See, e.g., JCT PENALTY STUDY, supra note 35, at 222 (noting anecdotal evidence that corporate tax departments are evaluated based on tax savings achieved).

122. Jeffrey Madrick discussed these pressures in an interview with Michael C. Jensen, emeritus professor at Harvard. According to Jensen:

What we learned from the $1990 \mathrm{~s} .$. is that when a company's stock is overvalued it sets in motion a set of organizational pressures that can destroy rather than create shareholder value. Honest managers were so swept up by the need to produce rising profits just to keep their jobs, and their small fortunes, that they stepped over the line. Overvalued stocks are like managerial heroin.

Jeffrey Madrick, Economic Scene: Are Corporate Scandals Just Greed, or a Predictable Result of a Theory?, N.Y. TiMES, Feb. 20, 2003, at C2.

123. See, e.g., Valuation of Intangibles for Financial and Tax Purpose, or EPS vs. The IRS, 55 THE TAX EXECUTIVE 218, $221 \mathrm{n} .3$ (May-June 2003) (warning in an article published by organization of corporate tax professionals that a recent trend to emphasize profit-making as a goal of corporate tax departments may be misguided).

124. See supra notes 39, 71 and accompanying text. See also ENRON TESTIMONY, supra note 62, at 7, 9 (stating that Enron's tax department became "a profit center for the company"). 
on Taxation Chief of Staff Lindy Paull warned in presenting the staff's report on Enron's tax returns, government watchdogs are no match for these new corporate tax profit centers. ${ }^{125}$

\section{Conflicted Auditors}

During the late 1980s and 1990s, consulting, much of it involving the design and implementation of aggressive tax transactions, became a substantial moneymaker for accounting firms. ${ }^{126}$ Accenture, the Arthur Andersen consulting arm that was separated from Andersen shortly before Andersen disintegrated, provided cross-over revenues to support Andersen's audit business for several years before the spin-off. ${ }^{127}$ Auditors continue to earn lucrative fees from tax consulting for their audit and non-audit clients, even after the Sarbanes-Oxley focus on potential conflicts in those services. ${ }^{128}$

Tax shelter consulting with "value pricing" creates conflicts of interest that place considerable pressure on audit standards. The determination of accruals for contingent tax liabilities is an important part of the auditor's certification of the financial statement. ${ }^{129}$ The operative standard for making the determination indicates that an accountant need

125. See Warren Rojas, Enron Report Reinforces Need for Antishelter Bill, Taxwriters Say, 98 TAX NOTES 1031 (2003).

126. Prepared Testimony of Peter L. Faber, Federal News Service, Mar. 8, 2000. See also Bryan-Low, supra note 28 (reporting that "sales of nonaudit services grew over the past decade as the big firms sought to counter flagging audit revenue"); Sheryl Stratton, SEC Looks at the Sale of Aggressive Products to Audit Clients, 87 TAX NOTES 13 (2000) (quoting testimony of Peter Faber of McDermott Will \& Emery before the Senate Finance Committee that accounting firms are increasingly under internal pressure as "commission sales[persons]" to develop and sell tax ideas "for which they can charge a percentage of tax savings").

127. See FINAL ACCOUNTING, supra note 25, at 87-88. After the spin-off of Accenture, tax services continued to buttress the revenues of the firm. Id. at 98 (noting that Andersen retained "a plateauing audit business, a small tax business, and a fast-growing but still relatively small consulting business"). See also Jennings, supra note 18, at 214-18 (reporting that Andersen received \$25 million for its audit work for Enron compared to $\$ 27$ million for tax and other consulting services for Enron).

128. See Cassell Bryan-Low, Keeping the Accountants From Flying High, WALL ST. J., May 6, 2003, at C1 (indicating that a large percentage of the overall revenues of the Big Four accounting firms came from tax work in 2002: $36 \%$ for PwC, $21 \%$ for Deloitte, 38\% for E\&Y, and 37\% for KPMG); Cassell Bryan-Low, Accounting Firms Earn More From Consulting, WALL St. J., Apr. 16, 2003, at C9 (reporting that PricewaterhouseCoopers earned \$17.4 million for tax work and only \$8.2 million from audit work for Caterpillar Inc. in 2002, including $\$ 13.9$ million "for services performed as a subcontractor for outside legal counsel"); Carrie Johnson, Surviving the Accounting Upheaval: Ernst \& Young Changing in Response to Pressures, WASH. PosT, July 30, 2003, at EO1 (indicating that Ernst had $\$ 4.5$ billion in revenues in 2002, $40 \%$ of which came from tax work and $50 \%$ from audit work); Bratton, supra note 34, at $11 \mathrm{n.30}$ (indicating that the Big Four accounting firms continue to receive $50 \%$ of their revenues from non-audit services).

129. The Arthur Young Court described this role as follows:

An important aspect of the auditor's function is to evaluate the adequacy and reasonableness of the corporation's reserve account for contingent tax liabilities. This reserve account, known as the tax accrual account, the noncurrent tax account, or the tax pool, represents the amount set aside by the corporation to cover adjustments and additions to the corporation's actual tax liability. Additional corporate tax liability may arise from a wide variety of transactions. The presence of a reserve account for such contingent tax liabilities reflects the corporation's awareness of, and preparedness for, the possibility of an assessment of additional taxes.

United States v. Arthur Young, 104 S. Ct. 1495, 84-1 USTC ๆ 9305 , aff 'g, rev'g and remanding 82-1 USTC ๆ 9320 (2d Cir.) (footnote omitted). 
not book a contingency if the tax position of non-liability claimed in the transaction is considered "probable." 130 If an opinion that a tax position is probable is provided, or arranged to be provided, by an audit firm in connection with its own tax services, it will have no incentive to raise doubts about the efficacy of the strategy or to require reserves to cover a contingent tax liability. Indeed, it is likely that the strategy's risk will receive no further analysis - either because the firm's core tax experts perform both the audit and consulting work, or because the firm's tax consultants would not tolerate a disclaimer of their work by their auditor colleagues. Although the circumstances are slightly different, a similar conflict of interest between client and auditor exists when an auditor that markets tax shelters reviews tax accruals for a "knock-off" strategy sold to its audit client by other accounting or law firms. ${ }^{131}$ Even when a tax-motivated transaction is designed by a client's internal tax department, non-audit consulting fees create a disincentive for an auditor to take a more conservative view of tax risk than that taken by the internal audit and tax departments.

Furthermore, the tax rules do not establish standards that adequately discourage aggressive advice. An adviser can recommend a return position to a client so long as the position has "a realistic possibility of being sustained on its merits." 132 The realistic possibility standard requires only a one-in-three probability of success. ${ }^{133}$ An adviser

130. See Elements of Financial Statements, Statement of Financial Accounting Concepts No. 6 q 35 48, If $35 \mathrm{n} .21$ (Financial Accounting Standards Bd. 1985) (indicating that only "probable" future payment obligations are treated as liabilities, where "probable" means "that which can be reasonably expected"); ACCOUNTING FOR CONTINGENCIES, Statement of Financial Accounting Standards No. 5 (Financial Accounting Standards Bd. 1975) (discussing treatment of contingencies); ACCOUNTING FOR INCOME TAXES, Statement of Financial Accounting Standards No. 109 (Financial Accounting Standards Bd. 1992) [hereinafter FAS 109] (providing general guidance for accounting for current and deferred tax liabilities and assets). See generally Jasper L. Cummings, Jr., Special Report, The Range of Legal Tax Opinions, with Emphasis on the 'Should' Opinion, 98 TAX NOTES 1125, 1129-31 (2003) (discussing the relationship of the various standards to the booking of tax reserves, and noting that the "probable" standard is considered to be higher than the standard required for valuation allowances under FAS 109).

131. See, e.g., Letter to Jonathan Katz from Professor Linda Beale and co-signers (Jan. 10, 2003) (hereinafter Beale Comment Letter), reprinted in Current and Quotable, Tax Profs Urged SEC to Take Tough Stance on Auditor Independence, 98 TAX NOTES 765-73 (2003) (providing examples of cloning of tax-driven products and discussing the inherent conflict of interest when an auditor that markets such products is required to audit its own or other similar products used by the audited company).

132. See I.R.C. $\$ 6694$ (a) (West 2004) (standard for purposes of the tax return preparer penalty under the Code); Circular 230, 31 C.F.R. $\S 10.34$ (a) (2003) (standard for advising return positions per rules governing practice before the IRS). If the position does not satisfy the realistic possibility standard, an adviser may still recommend it so long as it is not frivolous and is adequately disclosed to the IRS. Treas. Reg. $\S 1.6694-$ 2(c)(3)(i), Circular 230, 31 C.F.R. $\S 10.34(a)(2001)$.

133. Treas. Reg. $\$ 1.6694-2$ (b)(1) (as amended in 1991), Circular 230, 31 C.F.R. $\S 10.34(d)(1)$ (2003). Note that this standard is much less stringent than the standard that applies, under rules for practice before the IRS added in 1984, to an adviser who provides a "tax shelter opinion" for an investment directed to persons other than the client who engaged the practitioner to provide the advice. In such third-party-directed tax shelter opinions, the adviser must state whether the investor is more likely than not to prevail on the merits on each material issue or describe why that opinion cannot be given. See Circular 230, 31 C.F.R. $\S 10.33$ (c)(3) (2003) (defining "tax shelter opinion"); id. at $\S 10.33(a)(4)$ (requiring "more likely than not" standard for each material item or an explanation why it cannot be given). If possible, an adviser also must evaluate the transaction as a whole to determine whether the overall benefits are "more likely than not" to be realized. $I d$. at $\$ 10.33(\mathrm{a})(4)$. Circular 230 defines "tax shelter" as:

an investment which has as a significant and intended feature for federal income or excise tax 
who does not sign a client's return may even recommend a "nonfrivolous" position, if he advises the taxpayer that the position may be subject to penalty because it lacks substantial authority. ${ }^{134} \mathrm{~A}$ position with a mere five-to-ten percent chance of success may be nonfrivolous. ${ }^{135}$

The problem is made worse when auditors rationalize nondisclosure of aggressive corporate tax transactions under the IRS reporting rules. ${ }^{136}$ Former IRS Chief Counsel B. John Williams asserted that the major accounting firms are guilty of "wholesale failures to comply" with tax laws requiring disclosure of corporate tax shelters. ${ }^{137}$

\begin{abstract}
purposes either of the following attributes: (i) deductions in excess of income from the investment being available in any year to reduce income from other sources in that year, or (ii) credits in excess of the tax attributable to the income from the investment being available in any year to offset taxes on income from other sources in that year.
\end{abstract}

Id. at $\S 10.33(\mathrm{c})(2)$. These older tax shelter rules would not apply to non-audit tax services provided by an auditor for an audit client, except in those cases where the auditor is providing a tax opinion to the audit client to be used in promoting a transaction to other parties. The IRS has proposed to amend these opinion requirements to apply to a broader class of corporate tax shelters, but those amendments have thus far not been finalized. See Notice of Proposed Rulemaking, REG-111835-99, 66 Fed. Reg. 3276 (Jan. 12, 2001) (to be codified at 31 C.F.R. pt. 10) (proposing tax shelter opinion amendments to Circular 230); T.D. 9011, 2002-2 C.B. 356 (July 26, 2002) (to be codified at 31 C.F.R. pt. 10) (finalizing amendments to Circular 230 without including amendments relating to tax shelter opinions); Notice of Proposed Rulemaking, REG-122379, 68 Fed. Reg. 75186 (Dec. 30, 2003), reprinted in 2004 TNT 1-13 (Jan. 2, 2004) (proposing modifications to Circular 230 that change the standards for tax shelter opinions).

134. Treas. Reg. $\S 1.6694-2(\mathrm{c})(3)(\mathrm{ii})(\mathrm{A})$ (2003) (as amended in 1991). Under the rules for practice before the IRS in Circular 230, a similar rule provides that a non-signing adviser may advise a nonfrivolous position if the adviser alerts the taxpayer of "any opportunity to avoid the accuracy related penalty ... by adequately disclosing the position." 31 C.F.R. $\$ 10.34(a)(2)$ (2003). A nonfrivolous position is one that is not "patently improper." Treas. Reg. § 1.6694-2(c)(2) (2003) (as amended in 1991); 31 C.F.R. § 10.34(d)(2) (2003). Although the AICPA also imposes a realistic possibility standard on accountants who give tax advice, the standard is aspirational (using "should" rather than "must") and permits recommendation of a substandard position if disclosure is recommended. See AICPA, Statement on Standards for TaX Services No. 1 , TAX RETURN POSITIONS, STATEMENTS ON STANDARDS FOR TAX SERviCES NOS. 1-8 (Aug. 2000), available at http://www.aicpa.org (under "taxation") (last visited April 5, 2004). It is not clear whether ethical standards permit an attorney to recommend positions that do not satisfy the reasonable possibility standard. See Gould, supra note 80, at 536-37 (noting disagreement among lawyers on this issue, as revealed by statements of the ABA special task force and the ABA Tax Section).

135. See JCT Penalty Study, supra note 35, at 159-60 and Table 7 n.1 (suggesting a 5-10 \% likelihood of success for a nonfrivolous position, based on "a general consensus of scholars and practitioners"). As noted, a taxpayer-client risks a penalty if the position taken on its return is not supported by substantial authority under I.R.C. § 6662(b)(2), which is interpreted to correspond to somewhat less than a 50\% likelihood of successperhaps as low as $40 \%$. Id. See also Gould, supra note 80 , at 537 (noting IRS interpretation of $45 \%$ or higher likelihood of success).

136. See supra note 11 and accompanying text (corporate tax shelter regulations); infra Subpart V.A. (discussing reporting requirements under corporate tax shelter regulations).

137. Sheryl Stratton, Chief Counsel Sees Work on Guidance and Shelters Pay Off, 2003 TNT 47-2 (Mar. 11 , 2003) (quoting former IRS Chief Counsel B. John Williams Jr. regarding promoter failure to register tax shelters under \& 6111). Emst \& Young settled an IRS complaint of failure to register tax shelters for $\$ 15$ million. See Christopher Stem, Sprint May Switch to New Auditor, WASH. POST, July 15, 2003, at E05 (reporting E\&Y's \$15 million settlement with IRS re compliance with tax shelter registration and list maintenance requirements); Sheryl Stratton, E\&Y Settles Shelter Promoter Liability With IRS for $\$ 15$ Million, 100 TAX NOTES 10 (July 7, 2003) [hereinafter Stratton, E\&Y Settles] (reporting settlement and concern that the firm got off too lightly). 


\section{Inadequate Information About Risky Transactions}

Tax shelters are "structured to be impenetrable."138 This intentional complexity hides shelters from the IRS and prevents many company insiders from understanding details of aggressive tax planning. ${ }^{139}$ Personnel in internal tax and audit departments may be aware of a company's participation in aggressive tax transactions, and a company's senior executives (i.e., the CFO and CEO) can generally obtain information about such transactions from their staffs at the degree of detail they require. In many reporting companies, however, managers effectively control tax risk information and may provide nothing more than superficial information and aggregated data to company boards. As a result, directors may be in the dark about tax strategy risks and ill-equipped to make decisions about tax services provided by reporting companies' outside auditors. ${ }^{140}$

This lack of transparency results in considerable market distortion as well. In almost no case do investors have the information necessary to judge the tax risks of their investments. When corporations engage in potentially abusive tax transactions that they

138. Press Release, Lawrence H. Summers, Tackling The Growth of Corporate Tax Shelters: Treasury Secretary Lawrence H. Summers Remarks to the Federal Bar Association, Dep't of the Treasury Office of Public Affairs (Feb. 28, 2000), available at http://www.treas.gov/press/releases/ls421.htm (last visited Oct. 15, 2003).

139. I rely here on anecdotal evidence from conversations with various people who are tax practitioners at law firms or in corporate tax departments.

140. Directors of publicly held corporations are not typically vulnerable to shareholder suits in respect of corporate tax planning. Shareholder suits against directors for breach of the duty of care are generally difficult for shareholders to win. See, e.g., Margaret M. Blair, Directors' Duties in a Post-Enron World: Why Language Matters, 38 WAKE FOREST L. REV. 900 (forthcoming Fall 2003), available at http://papers.ssm.com/abstract= 416602 (last visited Oct. 15, 2003) (noting, at 16 in the SSRN version, that directors have considerable discretion in making good faith decisions about allocation of corporate resources); In re Caremark Int'l Inc. Derivative Litig., 698 A.2d 959, 967 (Del. Ch. 1996) (stating that a shareholder derivative suit for breach of duty is "possibly the most difficult theory in corporation law upon which a plaintiff might hope to win a judgment"). Directors can generally rely on the business judgment rule as a defense. See, e.g., McCall v. Columbia/HCA Healthcare Corp., 239 F.3d 808, 816 (6th Cir. 2001) (noting presumption of sound business judgment); Smith v. Van Gorkom, 488 A.2d 858 (Del. 1985) (indicating that shareholders must show gross negligence to overcome business judgment presumption and hold directors liable for breach of their duty of care). Although material misstatement of contingent tax liabilities could serve as a basis for shareholder suits under Rule 10b-5 and Section 10(b) of the 1934 Exchange Act, 15 U.S.C. $\S 78$ j(b); or Section 11 of the 1933 Securities Act, 15 U.S.C. $\S 77 \mathrm{k}(\mathrm{a})$; or the "controlling person" provision of Section 15 of the 1933 Securities Act, 15 U.S.C. $\S 770$, those claims are also difficult to prove. See generally In re Enron Corp. Sec., Der. \& ERISA Litig., 235 F. Supp 2d 549, 569-77, 595-98 (S.D. Tex., Dec. 19, 2002) (discussing liability under the listed provisions), dismissed by, in part, In re Enron Corp. Sec., Der. \& ERISA Litig., 2003 U.S. Dist. LEXIS 1668 (Jan. 28, 2003), dismissed by, in part, In re Enron Corp. Sec., Der. \& ERISA Litig., 258 F. Supp. 2d 576 (S.D. Tex., Mar. 12, 2003), motion granted by, motion denied by, dismissed by, in part, In re Enron Corp. Sec., Der. \& ERISA Litig., 2003 U.S. Dist. LEXIS 7632 (Apr. 24, 2003). Statutory defenses, including due diligence and reliance on expert opinions, are available to directors for claims under Sections 11 and 15 of the 1933 Securities Act. In re Enron, 235 F. Supp. 2d at 597. A Rule 10b-5 claim of misstatement under the 1934 Exchange Act requires a plaintiff to show scienter, causation and reliance. $I d$. at 571 . The Public Securities Litigation Reform Act, Pub. L. No. 104-67, 109 Stat. 737, requires considerable particularity of pleading for such claims. Id. at 570 . Note, however, that directors who serve on audit committees may now face a somewhat greater risk of suit if inadequate information about tax strategies is provided by subordinates or outside advisers to a company's auditors: a new rule under Sarbanes-Oxley prohibits officers or directors from making (or causing another to make) a materially false or misleading statement to an accountant in connection with audits or reviews of financial statements. 17 C.F.R. $\$ 240.13 \mathrm{~b} 2-2$ (2003). 
expect would be challenged if uncovered by the IRS on audit, they do not tout the information in their reports to the SEC or in their annual reports to shareholders. Instead, the descriptive sections of the company's periodic reports to the SEC are likely to provide at best sketchy information that is insufficient to understand how transactions work or to evaluate the purported tax benefits. ${ }^{141}$ Any material information about risky tax transactions tends to be hidden in aggregate numbers for tax liabilities in the balance sheet and deferred taxes in the income statement: the few details that may be released are likely to be buried in arcane language and aggregate numbers in footnotes to the financial statement. ${ }^{142}$ The resulting information asymmetry undercuts the efficient market hypothesis: ${ }^{143}$ that is, whenever there is such an asymmetry of information between buyer and seller, the market will be imperfect. ${ }^{144}$ As a result, a prudent corporation that insists on engaging in transactions only for reasons germane to its business may be at a competitive disadvantage in the marketplace, while corporations with high tax risks may reap undeserved rewards. The inappropriate reward structure may result in a vicious cycle of companies taking ever more aggressive tax positions to achieve new revenue targets.

The lack of transparency is aggravated whenever there is a conflict of interest between auditor and audit client. Such a conflict was obvious in the Sprint situation, where Sprint was ultimately forced to choose sides between its auditor and its executives. ${ }^{145}$ Similar conflicts of interest arise between an auditor and reporting company whenever the IRS questions a transaction devised by the auditor and not disclosed to investors. Although it might be in investors' overall best interest for companies to reveal participation in abusive transactions (so that investors can reduce

141. Tax information in financial statements is so restricted that it is difficult to discern even broader outlines of a corporation's tax status. See Gary A. McGill \& Edmund Outslay, Did Enron Pay Taxes? Using Accounting Information to Decipher Tax Status, 96 TAX NOTES 1125 (2002) (finding that gaps in financial reporting make it almost impossible to determine a corporation's federal income tax status from financial statements).

142. THE STREET, supra note 31 , at 157 (noting that "footnotes are sometimes purposely obfuscatory" because company managers "hide aggressive accounting maneuvers").

143. The efficient market hypothesis assumes that "the price of a stock embodies all available information that is relevant to its current and future earnings prospects." ROBERT FRANK, MICROECONOMICS AND BEHAVIOR 570 (McGraw-Hill 5th ed., 2003). See generally Robert M. Bushman \& Abbie J. Smith, Transparency, Financial Accounting Information, and Corporate Governance, 9 FED. RES. BANK OF N.Y. ECON. POL'Y REV. 65, 66 (2003) (indicating that transparency of financial accounting information permits investors "to identify promising investment opportunities," "discipline managers," and "reduce information asymmetries"); JoSEPH E. STIGLITZ, ECONOMICS 266-69 (W.W. Norton \& Co. 1993) (explaining the efficient market hypothesis); Eugene F. Fama, Efficient Capital Markets II, 46 J. FIN. 1575 (1991) (discussing general theory that prices of securities reflect available information).

144. See, e.g., STIGLITZ, supra note 143, at 388, 497-98 (discussing imperfect-market theorists, such as Kenneth Arrow of Stanford, and problems caused by asymmetric information); OREN BAR-GILL \& LUCIAN ARYE BeBChUK, MisRePorting CoRPORATE PERformanCE (Harvard Law and Economics Discussion Paper No. 400 , June 2003), available at http://ssm.com/abstract $=354141$ (last visited Oct. 15, 2003) (arguing that asymmetries of information coupled with misreporting of corporate performance distorts financing and investment decisions). Availability of information generally correlates with strong stock markets. See Rafael La Porta, Florencio Lopez-de-Silanes \& Andrei Shleifer, What Works In Securities Laws?, Working Paper, at 18 (July, 2003) (concluding from empirical research of securities laws in 49 countries that extensive disclosure requirements and relatively low burdens of proof correlate with development of strong stock markets).

145. See supra note 100 and accompanying text. 
their interest in those companies, if they choose), companies are unlikely to disclose that information for fear that disclosure will bring unwanted IRS attention, or even cause major investor bailouts that drive share prices down for remaining shareholders, such as managers with restricted shares.

Some advocates of limited regulation may counter that tax transparency is unnecessary, either because market mechanisms already adjust stock prices for risky tax planning or because investors do not care whether companies engage in aggressive tax avoidance transactions. ${ }^{146}$ The first claim, that markets adjust themselves, simply does not bear out when there are significant information asymmetries, as in the case of tax risks. ${ }^{147}$ Investor lack of information prevents market adjustments when a company enters into a risky transaction. Investors can respond only well after the fact, when a company is required to release information in its public reports about a major tax settlement or litigation.

The second claim rests on the view that investors will benefit from any reduction in corporate taxes due to utilization of an aggressive tax shelter because there will be more earnings to pay out to shareholders. This position disregards a number of issues. It is not clear, for example, that the incidence of corporate tax rests on shareholders rather than on consumers, employees, or creditors. ${ }^{148}$ To the extent corporate taxes are borne by other constituencies, shareholders would not benefit from tax shelter savings. Furthermore, aggressive transactions may cause significant internal inefficiencies, as corporate tax departments focus their energies on the search for cutting-edge shelter transactions. These inefficiencies may significantly reduce operating profits and stock prices. ${ }^{149}$ Moreover,

146. But see The Deflation Twilight Zone, BUSINESSWEEK ONLINE, July 25, 2003, available at http:/www.businessweek.com/investor/content/jul2003/pi200300724_4472_pi025.htm (last visited Mar. 31, 2004) (fund manager indicating that he does not invest in corporate bonds because of transparency issues).

147. See supra note 143 and accompanying text.

148. See, e.g., John Whalley, ThE InCIDENCE of THE CORPORATE TAX Revisited (Universities of Western Ontario and Warwick and NBER, Working Paper No. 97-7, Oct. 1997), at 1, available at http:/www.fin.gc.ca/taxstudy/wp97-7e.pdf (last visited Oct. 15, 2003) (noting that earlier commentary reflected a "disturbingly wide range of findings," with econometricians such as Krzyzaniak and Musgrave concluding that corporate taxes are borne by consumers, while general equilibrium theorists such as Harberger concluded that corporate tax is fully bome by shareholders; and concluding that the question may not lend itself to a "meaningful or concrete response."). But see JANE GRAVELLE \& KENT SMETTERS, WHO BEARS THE BURDEN OF THE CORPORATE TAX IN THE OPEN ECONOMY (NBER W8280, May 2001) available at http://papers.nber.org /papers/w8280 (last visited Oct. 15, 2003) (supporting Harberger's conclusion that most of the incidence is borne by capital, but some is exported); Jane G. Gravelle \& Laurence J. Kotlikoff, The Incidence and Efficiency Costs of Corporate Taxation When Corporate and Noncorporate Firms Produce the Same Good, 97 J. POL. ECON. 749 (Aug. 1989) (modeling different results from Harberger's); Amold C. Harberger, The Incidence of the Corporation Income Tax, 70 J. POL. ECON. 215 (1962) (seminal general equilibrium article).

149. Recent research suggests that aggressive tax planning by corporate managers also enhances their ability to divert corporate funds, whereas strong tax law enforcement increases stock value of companies by encouraging better corporate governance. MIHIR A. DESAI ET AL., THE PROTECTING HAND: TAXATION AND CORPORATE GOVERNANCE, (NBER, April 2003), available at http://www.nber.org/ confer/2003/urccf503/

mihir.pdf (last visited Oct. 15, 2003) (draft of paper to be presented at a May 9-10, 2003 NBER-Universities Research Conference on Corporate Governance). The authors suggest that the sheer complexity of Tyco's tax planning strategies (including incorporation in a tax haven country and manipulation of profit sources through intercompany loans) permitted its CEO and CFO to divert funds for personal use. Id. at 9 (noting that the balance sheet item for accrued federal income taxes was used to conceal $\$ 41$ million in bonus payments to executives). 
gains from tax shelters may be deceptive. At the time a company engages in a tax shelter, it may appear to reap a benefit, in terms of better cashflows and higher returns on equity, especially if it treats the transaction as significantly less risky than merited in its financial reporting and fails to reserve for a contingent tax liability. ${ }^{150}$ Once such a transaction is discovered and a tax deficiency assessed against the company, however, costs include not only the hourly fees of highly paid accountants and lawyers who represent the company before the IRS and the courts, but also the drain on high-level company personnel who may spend months or years supporting the defense through settlement, trial, or even appellate litigation. Even if the company ultimately wins its suit, these costs may be significant in comparison to the tax savings. A further cost is the reputational harm to the company once the problem becomes public. Even in a climate that has become more accepting of greed as a prime motivating factor, companies that are perceived to shirk their responsibilities to pay taxes through elaborate scams may lose investor and, perhaps even more importantly, consumer confidence. ${ }^{151}$ One would expect this to be especially true in the aftermath of the public outrage over the Enron, HealthSouth, Sprint and other tax and accounting scandals. Tax compliance responsibility may thus become a more visible issue in tandem with corporate social responsibility. ${ }^{152}$

\section{Regulatory Responses to the TAX SHELTER Problem}

This Part considers the regulatory response to aggressive tax planning. Subpart A briefly reviews the progress that the IRS has made in addressing tax shelters. Subpart B summarizes the treatment of auditor-provided tax services under Sarbanes-Oxley.

150. This seems more likely, of course, when the company's audit firm is also the tax shelter promoter. If the promoter has assured the company of a significant likelihood of winning on the merits if the shelter is challenged, it is unlikely to argue for treating the contingent tax liability as material.

151. The data on this is difficult to come by. The fact that a significant portion of the shareholders of Stanley Works voiced disagreement with its original decision to invert to an offshore company is one indication of investor concem. David L. Lupi-Sher, Stanley Works Encounters More Obstacles To Offshore Reincorporation, 2002 TNT 110-6 (June 7, 2002). Other commentators have argued that the result on balance is likely to be investor flight rather than investor delight. See, e.g., David Lenter et al., Public Disclosure of Corporate Tax Return Information: Accounting, Economics, and Legal Perspectives, 56 NAT'L TAX J. 803, 820-21 (Dec. 2003) (discussing survey showing that more than $70 \%$ of Americans consider good corporate citizenship in deciding whether to buy a company's product or its stock and suggesting that greater disclosure of tax information would encourage better compliance). See also Donald Alsop, Corporate Scandals Hit Home, WALL ST. J., Feb. 19, 2004, at B1 (discussing decline of corporate reputations in 2003 among consumers, due to "corporate fraud, deception and greed").

152. See Cynthia A. Williams, The Securities and Exchange Commission and Corporate Social Transparency, 112 HARV. L. REV. 1197, 1201, 1276-96 (1999) [hereinafter Williams, Social Transparency] (discussing the importance of wider disclosure regarding corporate social responsibility); Cynthia A. Williams, Corporate Social Responsibility in an Era of Economic Globalization, 35 U.C. DAVIS L. REV. 705 (2002) [hereinafter Williams, Corporate Social Responsibility] (discussing wider disclosure). A new service from S\&P that rates public companies based on their openness with information about the company underscores the interest of market participants in adequacy of information after the Enron debacle. See Market Views From S\&P: Meet S\&P's Corporate-Disclosure Rankings, BUSINESSWEEK ONLINE, available at http://www.business week.com/print/investor/content/oct2002/pi20021015_6208.htm (last visited Oct. 15, 2003) (announcing the new service). 


\section{A. Tax Shelter Legislation and Regulations}

Congress historically responded to tax shelters with targeted provisions that explicitly disallowed a particular type of abusive transaction. ${ }^{153}$ Particularized responses, however, add additional layers of complexity to an already complex Code. ${ }^{154}$ Furthermore, whenever a specific transaction is prohibited by legislation, tax practitioners at even the most highly regarded law, accounting, and consulting firms revel in their ability to develop replacement transactions that appear to adhere to the new, literal requirements of the Code. ${ }^{155}$

At various times over the last decade, Congress has also considered codification of the economic substance test, a general anti-abuse judicial doctrine that may disallow transactions that appear to comply with technical tax provisions. ${ }^{156}$ The Senate included

153. See, e.g., I.R.C. $\S 163($ j) (West 2004) (disallowing excess interest deductions on debt owed to foreign affiliates); I.R.C. $\S 163(\mathrm{e})$ (West 2004) (explaining AHYDO rules disallowing portions of original issue discount deductions where the yield on the obligation suggests a rate of return more appropriate to equity than to debt). For an overview of typical tax shelters of the late seventies and early eighties, which generally involved wealthy individuals making minimal investments to purchase real assets through limited partnerships funded primarily with non-recourse debt, see generally Paul J. Sax, Lawyer Responsibility in Tax Shelter Opinions, 34 TAX LAW. 5, 5-14 (1980) (discussing common shelters); JAMES C. GARAHAN \& JEFFrEY B. Rudman, Tax Shelters in Trouble: Private and Public Litigation (Practicing Law Institute 1985) (discussing shelters and appending relevant IRS manual sections on various equipment leasing and real estate shelters); Robert Daniel Fierro, Tax Shelters in Plain English: New Strategies for the 1980S (Farnsworth Publ. Co., Inc. 1981) (discussing strategies). The response to this earlier cycle of shelters was similar to today's response to corporate tax shelters: particularized anti-abuse provisions (such as the at-risk and passive loss rules), increased enforcement efforts, and enhanced reporting requirements. See, e.g., Sax, supra (providing a chronology of legislative and administrative responses); JULIAN BLOCK, FEDERAL TAXES, BULletin 41, SECTION 3, TAX Shelters: A GUIDE TO THE NEW REPORTING REQUiREMENTS (1985) (providing a brief history of shelters followed by a discussion of newly enacted tax shelter registration and promoter list requirements under $\S \S 6111$ and 6112 ).

154. See, e.g., McMahon, supra note 39, at 1737-47 (suggesting particularized changes to the Code to cope with corporate tax shelters as alternatives to codification of an economic substance doctrine and noting the considerable complexity that such changes would entail). A good example of the complications from specific anti-abuse provisions is provided by the various anti-deferral provisions in the foreign source income section of the Code. See, e.g., I.R.C. $\$ \S 951-960$ (West 2004) (governing controlled foreign corporations); I.R.C. $\S \S 1291$ 1298 (West 2004) (passive foreign investment companies); I.R.C. $\S \S 551-558$ (foreign personal holding companies); and I.R.C. $\S \S 541-547$ (West 2004) (personal holding companies).

155. See, e.g., James Whitmire \& Bruce Lemons, Special Report: Putting Tax Shelters At Risk-Discussion and Proposal for Change, 98 TAX NOTES 585, 587 (2003) (stating that "[n]arrowly tailoring a solution to a particular problem... increases taxpayers' ability to maneuver around the provision"). For example, a prominent member of the New York State Bar Association has been heard to say that the most satisfying aspect of structuring a transaction is to turn an anti-abuse provision against the government-i.e., to use what is intended to be an anti-abuse provision as a means to accomplish a particular structured tax transaction.

156. See supra note 39 (discussing economic substance and providing a bibliography of commentary on codification). Beginning in 1999, Representative Doggett has proposed legislation in the House of Representatives that would codify the economic substance doctrine. See Abusive Tax Shelter Shutdown Act of 1999, H.R. 2255, 106th Cong. (1st Sess. 1999); Abusive Tax Shelter Shutdown Act of 2001, H.R. 2520, 107th Cong. (July 17, 2001); Abusive Tax Shelter Shutdown and Taxpayer Accountability Act of 2003, H.R. 1555, 108th Cong. (2003). In another attempt at codification, Representative Thomas introduced the American Competitiveness Act of 2002, H.R. 5095, 108th Cong. (2002). The Senate has considered similar proposals. See, e.g., Finance Releases Revised Draft of Tax Shelter Legislation, in HIGHLIGHTS \& DOCUMENTS Doc 200025409 (Oct. 5, 2000); S. Doc. No. 2000-25409 at 325-8 (Oct. 5, 2000), available at http://finance.senate.gov/fin- 
a version of economic substance codification in the 2003 tax bill, ${ }^{157}$ but that provision, along with various penalty enhancements, was not enacted into law. 158

Perhaps the most successful recent approach has been development of broad disclosure requirements. ${ }^{159}$ In the Taxpayer Relief Act of $1997,{ }^{160}$ Congress extended an earlier, narrow shelter registration requirement to apply to corporate tax shelters. A shelter, defined as "any entity, plan, arrangement, or transaction" that has "a significant purpose" to avoid corporate taxation, must be registered if offered confidentially for fees aggregating more than $\$ 100,000 .{ }^{161}$ Registration was intended to provide early information to Treasury, so that it could address potentially abusive transactions marketed under confidentiality agreements before they spread to a large cadre of corporate participants. It was also hoped that distaste for registration would serve as a disincentive to deter corporations from entering into registration-required transactions. ${ }^{162}$ In conjunction with the registration requirement, the 1997 act also provided that the twenty percent substantial understatement penalty would apply to tax shelters that have "a significant purpose" of tax avoidance or evasion. ${ }^{163}$

Treasury developed detailed reporting requirements for corporate tax shelters under the 1997 act, issuing proposed and temporary regulations in February 2000. ${ }^{164}$ Treasury

leg.htm (10-05-00 Draft Staff Proposal on tax shelters) (Roth-Moynihan bipartisan staff proposal on tax shelters, providing a $40 \%$ penalty for understatements in connection with "abusive tax shelter devices" as determined by application of the economic substance and business purpose doctrines); The Tax Shelter Transparency Act, S. 2498, 107th Cong. (2002) (tax shelter legislation introduced by Senators Baucus and Grassley).

157. See CARE Act of 2003, S. 476, 108th Cong. (2003) (incorporating enhanced reporting and penalty provisions from the Tax Shelter Transparency Act, S. 2498, as approved by the Senate Finance Committee in 2002, and codification of the economic substance doctrine from the American Competitiveness and Corporate Accountability Act of 2002, H.R. 5095 (2002), introduced July 11, 2002, by Rep. Bill Thomas).

158. See Jobs and Growth Tax Relief Reconciliation Act of 2003, Pub. L. No. 108-27, 117 Stat. 752 (2003); H.R. REP. No. 108-126, Part V, Subpts. A, B (2003) (indicating that Congress did not include various provisions designed to curtail tax shelters or the Enron-related tax shelter provisions passed by the Senate).

159. Congress began enhancing disclosure requirements even prior to passage of the Tax Reform Act of 1986. The Tax Equity and Fiscal Responsibility Act of 1982 amended various procedural and penalty provisions related to sheltering transactions. See Tax Equity and Fiscal Responsibility Act of 1982, Pub. L. No. 97-248, 96 Stat. 324 (1982) (enacting the substantial understatement penalty). The Deficit Reduction Act of 1984 added a significant provision requiring promoters to maintain lists of investors in any "potentially abusive tax shelter," defined by reference to shelters as to which registration is required under $\S 6111$, an earlier provision for tax shelters offered confidentially. See Deficit Restoration Act of 1984, Pub. L. No. 98-369, § 142(a), 98 Stat. 494 (1984) (adding I.R.C. $§ 6112$ listing requirement). Today, there appears to be a "working consensus" in favor of disclosure. Sheryl Stratton, Shelter Disclosure, Doctrine Codification Debated, 99 TAX NOTES 25 (2003) (reporting "'working consensus' of industry, government, and congressional staffers that disclosure is the best approach to the shelter problem").

160. The Taxpayer Relief Act of 1997, Pub. L. No. 105-34, 111 Stat. 788, $\S 1028$.

161. I.R.C. $\S 6111(\mathrm{~d})(\mathrm{A})$-(C), as added by Pub. L. No. 105-34 $\S 1028$ (a) (1997) (applying to any such shelter for which interests are offered to participants after the date on which Treasury regulations are promulgated).

162. HOUSE OF REPRESENTATIVES COMMITTEE ON THE BUDGET, H.R. REP. NO. 105-148, at 469 (1997).

163. I.R.C. $\S 6662(\mathrm{~d})(2)(\mathrm{C})($ iii) (West 2004). The earlier version of this provision had required that tax evasion be the principal purpose of the transaction. This more general definition of "tax shelter" is not subject to the additional requirements, applicable to "corporate tax shelters" under I.R.C. § 6111 , that the transaction be confidential and subject to promoter fees of $\$ 100,000$ or more.

164. See I.R.S. Ann. 2000-1, 2000-1 C.B. 294 (announcing release of temporary and proposed regulations); 
finalized the corporate tax shelter regulations on February 27, 2003. ${ }^{165}$ A key feature of the corporate tax shelter regulations is the requirement that any taxpayer that engages in a "reportable transaction" must report the transaction to the IRS in connection with the filing of the taxpayer's return. ${ }^{166}$ The regulations designate six categories of reportable transactions that have a potential for tax avoidance, described generally as follows:

transactions identified by notice or other guidance as a tax avoidance transaction ("listed transactions");

confidentially marketed transactions;

contractually-protected-fee transactions;

certain loss transactions;

transactions with book-tax differences exceeding \$10 million; and

tax credit transactions in respect of assets having short holding periods. ${ }^{167}$

The regulations exempt certain ordinary course-of-business transactions that would otherwise come within one of the six categories, ${ }^{168}$ and revenue procedures list types of losses and book-tax differences for which reporting is not required. ${ }^{169}$ The use of revenue procedures permits greater flexibility in changing the exceptions as experience demands. ${ }^{170}$ In the few years since the promulgation of the proposed regulations, the Service has used its notice authority effectively to identify and shut down a number of listed transactions. ${ }^{171}$

I.R.S. Notice 2000-15, 2000-1 C.B. 826 (identifying the first group of "listed transactions"); T.D. $8875,2000-1$ C.B. 761 (temporary and proposed regulations on customer list requirement for potentially abusive tax shelters under I.R.C. $\$ 6112$ ); T.D. 8876, 2000-1 C.B. 753 (temporary and proposed regulations on corporate tax shelter registration under I.R.C. $\$ 6111$ ); T.D. 8877, 2000-1 C.B. 747 (temporary and proposed regulations requiring disclosure of corporate tax shelters under I.R.C. $\$ 6011$ ); T.D. 9108, RIN 1545-BC76 (Dec. 29, 2003) (amending the final regulations to limit required disclosure of confidential transactions under section 6011); T.D. 9109, RIN 1545-AY97 (Dec. 29, 2003) (limiting reasonable-cause defense to accuracy related penalties where taxpayer fails to disclose).

165. See supra note 11 (Treasury decision finalizing regulations under I.R.C. $\S \S 6011,6111$, and 6112).

166. See Treas. Reg. $\S 1.6011-4$ (a) (2003) (requiring taxpayers to file a statement disclosing a reportable transaction with their tax returns).

167. See Treas. Reg. $\$ 1.6011-4$ (b) (2003).

168. Treas. Reg. $\$ 1.6011-4(\mathrm{~b})(3)(\mathrm{ii})(\mathrm{A})(2003)$.

169. See Rev. Proc. 2003-24, 2003-11 I.R.B. 599 (listing types of losses not taken into account in determining whether a transaction is a reportable tax shelter); Rev. Proc. 2003-25, 2003-11 I.R.B. 601 (listing sources of book-tax differences not taken into account in determining whether a transaction is a reportable tax shelter).

170. One cannot but expect that resourceful practitioners will focus on the exempted types of losses and book-tax transactions for potential mechanisms to generate new types of tax shelters that will remain hidden from IRS scrutiny. Because these exceptions are not set out in the regulations, however, the IRS can alter the exemptions without going through the long process required for regulations and thus respond fairly rapidly upon discovery of such developments.

171. See, e.g., I.R.S. Notice 2002-51 I.R.B. 826, 2001-34 I.R.B. 190 (updating the list of corporate transactions identified as "listed transactions"); I.R.S. Notice 2003-76, 2003-49 I.R.B. (Nov. 7, 2003) (updating list). I.R.S. Notice 2002-50, 2002-2 C.B. 98 (alerting taxpayers that a transaction utilizing a straddle, a tiered partnership structure, a transitory partner and the absence of a Section 754 election to claim a permanent 
In addition to registration and reporting of various tax shelters, a promoter of a "potentially abusive tax shelter" is required to maintain lists of investors in the shelter. ${ }^{172}$ The regulations provide that any listed transaction and any shelter that is required to be registered will automatically be considered a potentially abusive tax shelter. The investor list maintenance requirement also applies to any transaction that an advisor reasonably expects may become a reportable transaction under the regulations. ${ }^{173}$

The registration and listing requirements and reportable transaction designation are not perfect solutions. At least some transactions that should be allowed for tax purposes will be required to be registered, listed or reported, increasing transactions costs. Some taxpayers and advisers likely will resist reporting a transaction on a gamble that it will not be discovered on audit or through review of a promoter's other clients' tax positions. ${ }^{174}$ The IRS litigation against KPMG ${ }^{175}$ and the recent settlement with Ernst \& Young 176 evidence imperfect compliance with the regulations. The various dollar thresholds could lead promoters and advisers to rationalize non-reporting based on treating a particular shelter as though it were comprised of several smaller transactions that did not reach the threshold limits. The many exemptions for loss transactions may be substantially overbroad in exempting financial transactions that create circular cash flows and artificial losses under the guise of ordinary business hedging, currency or other transactions. Similarly, the exemption of large classes of book-tax differences may make it harder for IRS agents to determine whether disclosure requirements have been satisfied, unless the book-tax reconciliation schedule is revised. ${ }^{177}$ Shelter promoters may

noneconomic loss will be challenged under the partnership anti-abuse rule, the step-transaction, economic substance, business purpose and substance-over-form doctrines). This is the "PICO" transaction that formed part of the compensatory stock option shelter marketed to Esrey and LeMay by Ernst \& Young. See supra note 96 and accompanying text. The Service has recently changed its position with respect to the listing of certain cross-border foreign tax credit transactions described in I.R.S. Notice 98-5, 1998-I.C.B. 334. See I.R.S. Notice 2004-19, 2004-11 I.R.B. 1 (Feb. 17, 2004).

172. I.R.C. $\S 6112$ (West 2004). See supra notes $86-93$ and accompanying text for discussion of litigation on this issue.

173. See Treas. Reg. $\S 301.6112-1(b)$ (2003) (establishing the categories discussed in the text, and including an additional type of potentially abusive transaction in $\S 301.6112-1(\mathrm{~b})(2)(\mathrm{i})(\mathrm{C}))$.

174. KPMG explicitly decided not to register its tax shelter transactions. See KPMG REPORT, supra note 92, at 13-14 (indicating that a senior KPMG tax professional explicitly advocated ignoring registration requirements and "coldly calculated" that penalties for one shelter would be insignificant in comparison to fees earned).

175. United States v. KPMG LLP, 237 F. Supp. 2d 35 (D.D.C. 2002). KPMG's response to the IRS's pursuit of information in connection with its promotion of the FLIP/OPIS shelter strategy, supra note 86 and accompanying text, is illustrative of the difficulty in overcoming audit firms' and other shelter promoters' views that they are merely applying the technical rules for the benefit of their clients. As to the Jacoboni FLIP/OPIS Shelter, KPMG claimed that it was neither a shelter "promoter" within the meaning of I.R.C. $\$ 6111$ (d)(2), nor an organizer or promoter of "potentially abusive tax shelters" within the meaning of I.R.C. $\$ 6112(a)$, and that it did not offer advice that satisfied the shelter definition in I.R.C. $\S 6112$ (b). See Jacoboni Complaint, supra note 40 , at $₫ 31$.

176. See Sheryl Stratton, supra note 137 (reporting settlement and concern that firm got off too lightly).

177. See Lillian Mills \& George A. Plesko, Bridging the Reporting Gap: A Proposal For More Informative Reconciling of Book and Tax Income, 56 Nat'l Tax J. 865 (Dec. 2003) (indicating need for more detailed information on book-tax reconciliation ); see also supra note 141 (noting difficulty of ascertaining corporate tax status from financial statements). After the preliminary release of this Article on the SSRN network in Fall 2003, Treasury proposed a more detailed book-tax reconciliation schedule for large corporations. See I.R.S. News Release, IR-2004-14 (Jan. 28, 2004) (releasing new Schedule M-3), available at http://www.irs.gov/busin 
also integrate shelter transactions into larger non-shelter transactions in such a way that the promoter or participant is persuaded that the arrangement can only be viewed as an integrated whole as to which disclosure is not necessary. Ferreting out potential ambiguities in the reporting rules may also convince those who structure or participate in a particular transaction that it is not reportable. ${ }^{178}$ The IRS' lack of detailed, segregated data for each individual return may provide an incentive for such direct evasion of the reporting obligation: most return information is aggregated so that it is extremely difficult to identify abusive transactions and trace purported tax benefits reported to a particular abusive transaction. ${ }^{179}$ Shelter techniques not captured by the current triggers or lists of reportable transactions would also avoid disclosure without any risk of penalties for failure to disclose. Unethical tax advisers may simply delay formalizing their advice until after clients' returns are filed, to claim applicability of an exception to reporting for postreturn advice. ${ }^{180}$

Although these lingering concerns suggest that the corporate tax shelter regulations will not wholly eliminate reporting problems, the regulations provide a workable mechanism that permits the government to identify the most egregious corporate tax shelters for enforcement purposes. ${ }^{181}$

esses/corporations/article/O, id-1 19992,00.html (last visited Mar. 31, 2004). Use of a more detailed book-tax reconciliation schedule of this type should make tax returns more transparent for audit purposes, but the schedule will likely not provide sufficient information to directors and shareholders to satisfy the needs discussed in the text.

178. For example, an Ernst \& Young spokesperson suggested that ambiguities in the earlier corporate tax shelter regulations were the cause for Ernst's failure to report certain shelters. See supra note 176 and accompanying text. See also James M. Peaslee, Official Announcements, Notices, and News Releases; Treasury Tax Correspondence, Attorney Suggests Adopting Excess Basis Rule to Find Abusive Tax Shelters, 2003 TNT 22-47 at 44 (Feb. 3, 2003) (stating that "I am aware of horror stories about people acting as promoters and denying it based on various flimsy arguments"). Peaslee's comments also expressed concerns about the ambiguities of the broader contractual indemnities triggered in the proposed regulations, noting that many customized indemnities might make transactions that are "obviously not tax shelters" subject to reporting. Id. On the other hand, the IRS's decision to adopt a very narrow contractual protection trigger that looks only to promoter fees may well cause it to miss customized shelter transactions that are developed on a negotiated basis with advisers, such as investment banks, and protected by extensively negotiated tax indemnity agreements or insurance.

179. "Unlike the reams of information collected by the SEC, the IRS gets scant data in a tax return. The returns offer few clues as to what might be illegitimate." Nanette Byrnes et al., News: Analysis \& Commentary, Hacking Away-at Tax Shelters: Executive Dodges Have the IRS-and Congress-Up In Arms, BUSINESS WEEK ONLINE, Feb. 24, 2003, available at http://www.businessweek.com/print/magazine/content/03_08/b3821 $058 . \mathrm{htm}$ ?mz (last visited Oct. 15, 2003) (noting shareholder concerns about executives' participation in stock option shelters).

180. See Treas. Reg. $\$ 301.6112-1$ (c)(2)(iv) (2003) (providing that a person will not be a "material adviser" in respect of a transaction if that person's tax advice is not provided prior to the filing of a tax return reporting the transaction); Sheryl Stratton, Shelter Regs Less of a Nightmare But Still Burdensome, 98 TAX NOTES 1484 (Mar. 10, 2003) (reporting that popular changes to the reporting rules included elimination of a reporting requirement for "'after-the-fact' practitioners").

181. But see Ronald A. Pearlman, Demystifying Disclosure: First Steps, 55 TAX L. REV. 289 (2002) (examining utility of return disclosure and limitations of current disclosure requirements and sanctions); McMahon, supra note 39, at 1722 (noting that "the efforts of the IRS to combat this new wave of tax shelters through a program based on mandatory disclosure of certain transactions, coupled with settlements without penalties for certain voluntary disclosures, do not appear to be working overwhelmingly well" and that "tax shelters are continuing to proliferate"). 


\section{B. The Sarbanes-Oxley Auditor Independence Rules}

The enactment of Sarbanes-Oxley provided an opportunity for Congress and the SEC to consider the impact of tax risks on corporate governance, at least in the context of auditor provision of non-audit tax services. While there was some Congressional discussion of the potential conflicts of interest when auditors provide tax shelter planning, ${ }^{182}$ Sarbanes-Oxley as passed does not explicitly list non-audit tax services among the prohibited categories. In fact, it generally permits an audit firm to provide non-audit tax services other than those that fall within the prohibited categories of services, if pre-approved by the company's audit committee. ${ }^{183}$

The SEC proposing and adopting releases for the auditor independence rules were ambivalent about the extent to which non-audit tax services may compromise independence. On the one hand, the proposing release suggested that particular tax services, especially tax shelter strategies, should be evaluated in light of the principles elaborated in the legislative history. ${ }^{184}$ On the other hand, the adopting release justified

182. See, e.g., 148 CONG. REC. H1552 (daily ed. Apr. 24, 2002) (statement of Rep. Doggett) (stating that "the same accountants that are causing many of these problems... they are the 'tax shelter hustlers,' 'respectable accountants' who are out peddling dicey corporate tax loopholes"). The House report, however, justified the very limited ban on non-audit services by repeating concerns raised by auditors that "a broader ban on nonaudit services could undermine rather than improve the auditor's understanding of the audit client's business activities ... reduce corporate efficiencies and impair auditing firms' ability to attract and retain tax and other nonaudit personnel who are essential to the audit process." REPORT OF THE HOUSE COMMITTEE ON FinANCIAL SERVICES to ACCOMPANY H.R. 3763, H.R. ReP. No. 107-414, at 17 (Apr. 22, 2002). The Senate heard testimony supporting a "bright-line ban" on any non-audit work because of the "conflicting loyalties" when audit committees hire auditors but managers control all other types of non-audit work. See 148 CoNG. REC. S6331-S6332 (daily ed. Jul. 8, 2002) (quoting testimony by James E. Burton at CalPERS and John Biggs of TIAA-CREF, respectively); REPORT OF THE SENATE COMMITTEE ON BANKING, HOUSING AND URBAN AFFAIRS TO ACCOMPANY S. 2673, S. REP. No. 107-205, at n.23 and accompanying text (July 26, 2002). See also id. at 23 (quoting John Biggs' statement that "TIAA-CREF does not allow our public audit firm to provide any consulting services to us, and our policy even bars our auditor from providing [any] tax services").

183. Sarbanes-Oxley, supra note $2, \S 201(\mathrm{~g})$ (banning eight non-audit services and authorizing the PCAOB to ban others by regulation); Sarbanes-Oxley, supra note $2, \S 201$ (h) (providing that audit firms could "engage in any non-audit service, including tax services, that is not described in any of paragraphs (1) through (9) of subsection ( $\mathrm{g}$ ) for an audit client, only if the activity is approved in advance by the audit committee of the issuer"). See Letter to Jonathan Katz from Professors Calvin Johnson, Linda Beale, \& Elena Marty-Nelson as principal drafters with twenty-five co-signers, Jan. 10, 2003, reprinted in Current and Quotable, Tax Profs Urged SEC to Take Tough Stance on Auditor Independence, 98 TAX NoTES 765-73 (2003) (arguing that the language of the Act should be read to ban any tax services that come within the prohibited categories); See also Beale Comment Letter, supra note 131 (same, with more extended arguments for banning all but the most routine tax services); Beale, supra note 34 , at 7-8 (same). There is no consensus regarding which tax services, if any, may be banned because they come within the otherwise prohibited types of services in categories 1-8. See, e.g., George R. Goodman, The Taxpayer's and Tax Adviser's Guide to Sarbanes-Oxley, 100 TAX NoTES 691, 706 (2003) (suggesting the prohibited expert services category could be understood to include representation in an administrative proceeding or providing a tax opinion letter in connection with a transaction, and that the prohibited valuations category could be understood to include some tax valuation services, in spite of the SEC's explicit statement permitting transfer pricing, if tax positions based on such valuation services are a material part of tax issues on audit).

184. See Proposed Rules: StRENGTHENING the Commission's REQUiREMENTS REgARDING AUDITOR INDEPENDENCE, Exch. Act Rel. Nos. 33-8154, 34-46934, File No. S7-49-02, 67 Fed. Reg. 76780 , 76798 (Dec. 2, 2002) (to be codified at 17 C.F.R. pt. 210, 240, 249, 274), available at http://www.sec.gov/rules/proposed/338154.htm (last visited Oct. 20, 2003) (stating that "[c]lassifying a service as a 'tax service' however, does not 
permitting auditor tax consulting because of "detailed tax laws" and IRS audits: 185 the uneasy implication is that IRS enforcement provides some kind of safeguard against auditor conflicts of interest. ${ }^{186}$ The adopting release specifically exempted transfer pricing studies, cost segregation studies and other tax valuations from the banned valuation services. ${ }^{187}$ It took a narrow view of advocacy that draws a line that is difficult to justify, permitting audit firms to represent audited companies in administrative proceedings but not in court. ${ }^{188}$ Rather than promulgate an outright prohibition on auditor participation in planning and implementation of tax shelters, the adopting release merely cautions that an audit committee should "nonetheless" "scrutinize carefully" any decision to retain the company's auditor for tax avoidance transactions recommended by the auditor that may have no business purpose. ${ }^{189}$

mean that the service may not be within one of the categories of prohibited services or may not result in an impairment of independence under Rule 2-01(b)," and suggesting that the audit committee should be guided in its determination by the "basic principles which cause an auditor to lack independence with respect to an audit client"). Auditors responded to this statement by lobbying vigorously against any restrictions on non-audit tax services, on the grounds that consulting contracts did not result in compromises of auditing standards but restrictions on non-audit services, especially tax planning, would result in loss of top talent and inferior audits. See, e.g., Beale, Developments, supra note 34, at 10 (discussing audit firm comments on the proposing release); THE STREET, supra note 31 , at 129-30 (discussing rationales for not restricting non-auditor services). The AICPA asserted that the SEC could not draw an appropriate line between prohibited and permitted tax planning services, other than a very narrow rule prohibiting transactions that have only a tax avoidance purpose, given the inability of Congress and the Treasury to provide a clear definition of abusive tax shelters. See AICPA Letter to SEC Supports New SEC Rules For Accountant's Independence And Offers Suggestions, 2003 TNT 9-13, ๆๆ 91-96 (Jan. 14, 2003) [hereinafter AICPA Letter].

185. See Final RULES: STRENGTHENING the Commission's REQUiREMENTS REgarding AuditoR INDEPENDENCE, Rel. Nos. 33-8183, 34-47265, 35-27642, IC-25915, IA-2103, FR-68, File No. S7-49-02 (Feb. 24,2003 ) (to be codified at 17 C.F.R. pt. 210, 240, 249, 274), at 21-22, available at http://www.sec.gov/rules/final/33-8183.htm (last visited Oct. 20, 2003) [hereinafter FINAL RULES] (reiterating a statement made in the proposing release that "[ $t]$ ax services are unique among non-audit services for a variety of reasons. Detailed tax laws must be consistently applied, and the Internal Revenue Service has discretion to audit any tax return. Additionally, accounting firms have historically provided a broad range of tax services to their audit clients.").

186. Reliance on IRS enforcement of the tax laws to counter the auditor independence problems of auditor provision of non-audit tax services is misguided. IRS enforcement of the tax laws cannot ensure that auditors who provide non-audit tax services will not have conflicts of interest when they audit their own tax work for financial statement certification, advocate for their audit clients in administrative proceedings, or promote the audited company's interest (rather than the public's) by assisting in structuring and implementing risky tax shelters. The fact that there are tax rules and audits to attempt to expose those who do not follow the rules is irrelevant to the conflict of interest question.

187. FinAl RULES, supra note 185 , at 14,22 . This statement could be viewed as undercutting the reforms contemplated by the Act, since such services were permitted under express exemptions in the earlier Levitt rules that were not retained in the Act.

188. Id. at 22. Some have suggested, however, that the ban on auditor provision of expert services might be read to encompass auditor representation of an audit client in a tax proceeding. See Goodman, supra note 183, at 706 (suggesting that administrative proceedings may involve expert services for the purpose of advocating a client's interest and thus remain "an area of controversy").

189. FINAL RULES, supra note 185 , at 22 . In approving the final rules, "[t]he Commissioners indicated that they were trying to get at tax plans, strategies, or products that were not related to the day-to-day business of the issuer, but rather those that "just showed up at the door" "where the accounting firm is acting as a salesperson." Saba Ashraf \& Pinney L. Allen, The Changing Landscape for Tax and Other Services: The Impact of SarbanesOxley: Part 2, 30 CORP. TAX'N 3, 7 (2003). See SEC Open Meeting Webcast (Nov. 19, 2002) available at http://www.sec.gov/news/openmeetings.shtml (last visited Oct. 20, 2003). Arthur Levitt, who supports an 
The problems resulting from the lack of tax risk information are exacerbated in an environment where investment banks and their sophisticated legal advisers, on the one hand, and audit firms with their increasingly multidisciplinary practices, on the other, are able to serve as "one-stop shopping centers" that devise and implement strategies that manipulate the tax laws. This practice increasingly leaves reporting companies at risk of tax liabilities, interest and penalties for which the financial statement includes no reserve. Without greater transparency, auditors can take advantage of their position as trusted advisers with insider knowledge of audit clients' extraordinary transactions to promote risky shelters. In the absence of a clearer guideline from the SEC, audit committees will likely find it difficult to disapprove such advice merely because they are urged to give careful scrutiny to transactions that lack business purposes.

\section{PROPOSAL FOR A MULTIDISCIPLINARY SEC APPROACH TO TAX RISK}

The SEC's approach to tax services ${ }^{190}$ places too little emphasis on the importance of accurate assessment of tax risks for financial accounting purposes and disregards key factors in ensuring auditor independence and financial statement accuracy. The lack of mandated disclosure about tax risks sows confusion and opportunities for intentional

outright ban on tax shelter work by audit firms, views the final rules as "intensif[ying] pressure on audit committees not to allow the performance of tax shelter work by companies' auditors." Arthur Levitt Jr., The SEC's Repair Job, WaLl ST. J., Feb. 10, 2003, at A14.

Even if the cautionary note in the adopting release persuades some audit committees to be wary of approving audit firms' provision of tax shelter planning, the release provides little guidance to audit committees to help them in that scrutiny, other than emphasizing the need for a business purpose for tax planning transactions. Prior to the adoption of the final auditor independence rules, concerned academics urged the SEC to ban some tax services. See Letter from Johnson, Beale \& Marty-Nelson, supra note 183; Beale Comment Letter, supra note 131. After the rules were finalized, some advisers promoted broad pre-approval practices, leading commentators to urge the SEC to provide guidelines for audit committee review of audit firms' tax services. See Accounting: Consumer Groups Tell SEC that E\&Y Exploits Independence Rule 'Loopholes,' DAILY TAX REP. (BNA), July 11, 2003, at G5.

Although no formal action has been taken by the SEC, the SEC's Office of the Chief Accountant provided information about staff views on these matters in the form of answers to frequently asked questions. See Office of the Chief Accountant, Application of the January 2003 Rules on Auditor Independence: Frequently Asked Questions (Aug. 13, 2003), available at http://www.sec.gov/info/accountants/ocafaqaudind08 0703.htm (last visited Oct. 20,2003). The release indicates that SEC staff consider pre-approval policies to be satisfactory only if they are "detailed as to the particular services to be provided." Monetary limits and broad categorical approvals are inappropriate. Id. at Q/A 22-24. While this guidance should discourage audit committees from adopting the kind of broad pre-approval statements urged by firms like Ernst \& Young, the guidance remains vague. These restrictions fall far short of ensuring that audit committees are fully informed about tax risks of particular transactions at the time they make these decisions. Further action by the PCAOB, perhaps along the lines proposed in this Article, remains a possibility. See, e.g., Cassell Bryan-Low, Keeping the Accountants from Flying High, WALL ST. J., May 6, 2003, at Cl (quoting PCAOB acting chair Neimeier that the group will "look at the issue of tax services being performed by auditors"). Although the PCAOB has not yet promulgated any additional rules governing tax services, it has at least indicated that it intends to monitor closely auditor provision of tax services to audit clients. See Sheryl Stratton, Accounting Board Won't Define Tax Services, But Will Inspect Them, 108 TAX NOTES 330 (Oct. 20, 2003). In addition, Senator Levin recently introduced legislation in the Senate to ban auditor provision of tax shelter advice to audit clients. See S.1767, 108th Cong. (1st Sess.) (Oct. 21, 2003).

190. See FINAL RULES, supra note 185 and accompanying text (presenting the SEC's view that tax services are within the realm of the IRS and hence evaluated differently from other issues that affect the securities markets). 
obfuscation within a reporting company, between managers of a company and its board, and between a company and investors. The likely result is that investors, and perhaps even company boards and senior managers, cannot evaluate a significant aspect of a reporting company's risk structure-the reporting company's and the audit firm's tax risk profiles.

The following proposals encourage the SEC to interpret Sarbanes-Oxley in a way that protects investors through "strong regulation."191 Regulation should ensure that audit committees are appropriately prepared to make decisions about auditor provision of tax services and armed with the information necessary to monitor reporting companies' own aggressive tax transactions. Audits can thus be used to help audit committees tackle companies' overly aggressive tax strategies before those strategies lead to major enforcement actions by the IRS or revelations that affect stock prices. This can best be accomplished by putting auditors in a position that is essentially adverse to the interests of material tax advisers to the reporting companies they audit. Ensuring that auditors' assessments of tax risks are genuinely independent may offer the best remedy for the financial accounting problems related directly or indirectly to tax compliance and, as a corollary, to the corporate tax shelter problem itself.

\section{A. Ban on Tax Shelter Advising Services}

It is clear that a reporting company's external auditor's assistance in planning or implementing abusive tax shelters represents a grave conflict of interest under each of the principles that guided the prohibition of services in Sarbanes-Oxley. ${ }^{192}$ At the time of the adopting release for the final rules on auditor independence, the SEC may have been justified in limiting the prohibition of tax services to those that are both clearly violative of auditor independence and amenable to bright-line rules, such as the adopted ban on representation of audit clients in a court proceeding. Lobbyists pressed the view that it

191. See E-mail from Calvin H. Johnson to Jonathan G. Katz (Jan. 13, 2003) (regarding S7-49-02, arguing that strong regulation is more beneficial for markets than laissez-faire management) (on file with author).

192. See Bernard Wolfman, "Sarbanes-Oxley" Needs Fixing, U.S.L.WK., Aug. 13, 2002, at 2083 ("No auditor who has sold a company a tax shelter or other tax minimization plan should audit that company because clearly the auditor would be conflicted."); Beale Comment Letter, supra note 131 (supporting a complete ban on tax shelter design by auditors and also proposing that the SEC ban all but the most routine tax services by audit firms); Beale, supra note 34 , at 8 (same). The argument is as follows. To make the deal, the auditor may tend to cast an aggressive transaction as having a higher probability of success than reasonable. The audit firm may even arrange for a law firm to provide a protecting opinion if the IRS were to select the transaction for detailed review. In that context, the audit firm would likely insist that the fact that the transaction falls within the category of reportable transactions is of little consequence and should not cause the company to be concerned about the legality of the arrangement or to reserve for a tax contingency in its financial statement. In the most egregious cases where the audit firm and client do not intend to comply with IRS reporting requirements, having an audit firm provide the tax planning service to its audit client lowers the risk of detection. When the audit firm later assesses the impact of the transaction on the company's financial statements, it will inevitably downplay any doubts about the efficacy of the tax shelter. The audit firm's interest will prevent it from concluding that reserves are needed to cover a contingent tax liability. In the more egregious case of a failure to report a listed or reportable transaction, the auditor may actually obscure the transaction in the financial statements, notes and tax returns. The auditor may also downplay related information in explanatory materials. KPMG, for example, helped its tax shelter clients hide the magnitude of their gains and artificial losses on their tax returns by approving the reporting of only net gains through a grantor trust structure. See KPMG REPORT, supra note 92, at 14. 
would be difficult to develop rules limiting abusive tax planning, because of the failure of Congress or the Treasury to provide a clear definition of an abusive tax-motivated transaction. ${ }^{193}$ None of the comments proposed utilizing the IRS reporting requirements as a basis for securities market reporting. ${ }^{194}$

In contrast, today there are final corporate tax shelter regulations that provide a consistent disclosure approach to potentially abusive tax shelter transactions. Any corporation entering into a transaction will have to decide whether the transaction must be registered or reported under those regulations, and any material advisor will have to make the same judgment in determining its list-maintenance responsibility. The SEC can utilize those same categories to ban tax shelter planning by a reporting company's external auditors without engendering confusion. The PCAOB with SEC approval should therefore act immediately to add to the list of prohibited non-audit services the promotion, design, or assistance in execution of registered or reportable transactions or transactions for which investor lists are required to be maintained, as those categories are defined in the corporate tax shelter regulations. By relying on the categories already required for IRS reporting, the SEC can prohibit potentially abusive planning without developing its own independent definitions and without imposing additional costs on audit firms and reporting companies. ${ }^{195}$

There are several corollaries to the proposed ban. It should apply to auditor tax services for reporting company executives, if auditor services for executives are permitted at all. ${ }^{196}$ In addition, auditors should be prohibited from serving as accommodation parties ${ }^{197}$ in any of the banned categories of tax shelter transactions undertaken by their audit clients, whether or not the auditor designed or structured the transaction or provided advice to the reporting company in respect of the transaction. Finally, the auditor should not be permitted to provide an analysis of the tax consequences of such a transaction that the reporting company proposes to any third

193. See, e.g., AICPA Letter, supra note 184, at Tf $91,94,96$ (noting that "[t]he issue of what is a 'tax shelter' is a difficult one; indeed, the Congress, the Treasury Department, the Internal Revenue Service and tax practitioner organizations have all been trying to devise an appropriate definition of the term for the past several years-without success," claiming that "tax minimization activities ... are ... essential components of tax services," and arguing that the SEC should, at most, prohibit auditors from offering transactions "that have no business purpose other than tax avoidance").

194. See Beale Comment Letter, supra note 131, at 771-72 (urging that the SEC limit non-audit tax services to those related to routine tax preparation services or at least ban auditor provision of tax shelter planning, but without proposing an administratively feasible definition for tax shelter services to be banned). The idea that auditor consulting services represent serious conflicts of interest is, of course, not a new one. See, e.g., Richard L. Kaplan, Accountants' Liability and Audit Failures: When the Umpire Strikes Out, 6 J. ACCT. \& PUB. POL'Y 1, 6 (1987) (stating that "[i]f independence, a fragile concept under the best of circumstances, is to be maintained, accounting firms must refrain from providing such advisory services to audit clients").

195. Other commentators have also suggested that the two agencies should deal cooperatively with problems that impact both administrative areas. See, e.g., Cornelius C. Shields, Professor Comments On Possible Securities and Commodities Safe Harbor, 2003 TNT 103-91 (May 29, 2003) (letter to the IRS and Treasury suggesting that the SEC and IRS should work together through an "informal liaison" to create book and tax accounting conformity).

196. It would be preferable to prohivit an audit firm from providing any tax advice to an audited company's executives. See, e.g., RsPort of THE SENATE COMmITTEE ON BANKING, Housing AND URBAN AfFaIRS to ACCOMPANY S. 2673, S. REP. NO. 107-205, at 23 (June 26, 2002) (John Biggs' testimony regarding policy of TIAA-CREF not to permit its external auditor to provide tax services for its executives).

197. See supra note 40 and accompanying text (discussing accommodation parties). 
party, whether as a promoter, structurer, or participant. ${ }^{198}$ Each of these services jeopardizes an auditor's independence by creating clear conflicts of interest between the audit firm and the reporting company or its managers.

\section{B. Arming the Audit Committee with Information}

The centerpiece of the auditor independence rules is the effort to strengthen the hand of audit committees by increasing transparency. Accordingly, Sarbanes-Oxley requires audit committee pre-approval before an auditor can provide non-audit tax services for a reporting company. However, audit committee pre-approval decisions will be little more than a pro forma stamp of approval unless members have appropriate information on which to base such decisions. ${ }^{199}$ In other words, auditor independence cannot be assured so long as auditors provide any tax consulting beyond routine tax return preparation to audited companies, unless the audit committee is appropriately armed to apply "constructive skepticism" 200 to its decisions about additional tax services.

This Article therefore proposes that the corporate tax shelter reporting categories be used to create tax risk information for this purpose. The proposal for specific tax disclosure to the audit committee is divided into two parts. Section 1 describes tax information that the audit committee should have about the audit firm. Section 2 describes tax information that the audit committee should have about the reporting company.

\section{Audit Firm Tax Risk Profile}

The audit committee should receive information on audit firms to guide the audit committee in its roles as employer of the external auditor and final arbiter on the hiring of the external auditor to perform non-audit tax consulting. The information statements should be provided in a cumulative form at least annually, and should be updated in connection with the audit committee's review of quarterly or annual financial statements certified by the auditor. The disclosure should reveal the "audit firm's tax risk profile" in advising other clients (and the audited company, if not expressly prohibited) in respect of potentially abusive tax shelters. The tax risk profile would provide objective information regarding the extent of the audit firm's corporate tax shelter advising work, the audit firm's penalty history in respect of corporate tax shelters, and the audit firm's "cumulative failure rate" (defined below) in respect of corporate tax shelter advising. The audit firm would not need to disclose names of clients, information about particular tax

198. See generally Beale Comment Letter, supra note 131 (discussing the conflicts when an external auditor provides to an audit client a tax opinion or memorandum of law that may be used by the audit client in connection with a third party's participation in the transaction that is the subject of the opinion); Beale, supra note 34 (same). Groups of accounting professionals have also urged a reconsideration of the SEC's position on auditor-provided tax planning. See, e.g., Rosemary Schlank, Association for Integrity in Accounting Reveals Broad-Based Accounting Advocacy Platform, 98 TAX NoTES 2022 (Mar. 31, 2003) (discussing new accounting advocacy group).

199. See supra note 189 (noting comments to the SEC regarding Ernst \& Young's suggestion that broad pre-approvals would be appropriate and the SEC staff's response supporting more detailed pre-approval policies).

200. William Power et al., Bids \& Offers, Inside the World of Corporate Finance \& Wall Street, WALL ST. J., Mar. 21, 2003, at C5 (quoting Arthur Levitt's comments to investor-relations professionals). 
structures, or any other confidential information.

To demonstrate the scope of the audit firm's tax shelter work, the profile would include the number of new registration-required transactions, reportable transactions, and transactions for which the audit firm is required to maintain investor lists in respect of which the audit firm has advised any client during the reporting period and cumulatively over a twenty-year period, as well as a report of the aggregate purported tax benefits expected to be derived from those transactions. For example, the extent statistic for an audit firm that had promoted one shelter strategy to twenty clients who expected to save an aggregate $\$ 100$ million in taxes with the shelter and another strategy to forty clients who expected to save an aggregate $\$ 60$ million in taxes through the shelter would be sixty new shelters with an aggregate benefit of $\$ 160$ million. The audit firm's penalty history would set forth the aggregate amount and number of separate penalties assessed against the audit firm for failure to report or register a tax shelter or failure to maintain and provide investors lists during the reporting period and cumulatively over a twentyyear period. For example, Ernst \& Young's profile would include the $2003 \$ 15$ million settlement with the IRS, ${ }^{201}$ including the number of separate non-reported items.

The concept of a cumulative failure rate statistic is central to the disclosure requirement. The cumulative failure rate is intended to provide an objective measure of the credibility of the audit firm's tax advice in respect of reportable, registered, or listmaintenance transactions. It would disclose the proportion of all such transactions advised by the audit firm (on behalf of any company or individual, in the current or any prior reporting period) for which the purported tax benefits have been denied in part or in whole in a final determination (i.e., payment on audit, settlement or litigation of the tax shelter transaction) ${ }^{202}$ Of course, one would not expect the cumulative failure rate to be high; in fact, a failure rate greater than one or two percentage points would likely be extraordinary. ${ }^{203}$ The value in the statistic is the ability of audit committees to compare firms to identify the audit firms that provide prudent tax minimization advice. Without this tax risk profile information, an audit committee has no way to know whether an auditor's clients have had difficulty with the IRS, unless a case is litigated. Bringing the failure rate into the open should add an element of shame to the factors entering into a decision to hire an auditor for tax-advising services. In other words, a relatively high cumulative failure rate would suggest lack of credibility for an auditor's tax planning strategies. Avoiding such shameful statistics by more prudent tax-planning advice would

201. See supra note 137 (reporting settlement).

202. The rate should likely be determined excluding transactions for which only a de minimis portion of the purported tax benefit was denied. A portion of the purported tax benefit might be considered de minimis if it is less than $5 \%$ of the purported tax benefit of such transaction.

203. Failure rates will not be high for various reasons, not the least of which are the problems of underenforcement and underdetection discussed in Part IV, supra. Nevertheless, the comparative statistic should reveal the comparative aggressiveness of the tax advice offered by accounting firms. For example, suppose that Firm 1 advised clients in respect of an aggregate 1250 transactions and 25 of those transactions resulted in a non-de minimis denial of tax benefits, then Firm 1's cumulative failure rate would be $25 / 1250$ or $2 \%$. If Firm 2 advised clients in respect of 1250 transactions and only five of those transactions resulted in a non-de minimis denial of benefits, the cumulative failure rate for Firm 2 would be only $5 / 1250$ or $0.4 \%$. Although the percentages in both cases are relatively low, Firm 1's significantly higher cumulative failure rate should be viewed as indicative of riskier tax advice-i.e., tax advice that is more likely than that of Firm 2 to take overly aggressive positions that may lead to tax deficiencies. 
operate as a disincentive to the auditor to promote overly aggressive tax planning to its clients. At any rate, it would provide objective guidance to an audit committee in evaluating the auditor's credibility in respect of tax-minimization techniques and in comparing the relative competence of various audit firms in the area of tax minimization techniques.

This report can be made available at only nominal cost to auditors and reporting companies. The corporate tax shelter regulations already require promoters and participants to determine whether reporting, registration or investor-list maintenance is required for particular tax-motivated transactions. If the SEC bans auditor planning in respect of those transactions for which registration, reporting or list maintenance is required, no additional assessment need be done to determine whether auditor tax consulting is permitted for a particular transaction. Similarly, because an accounting firm that provides any tax shelter planning must determine what reporting is required in each case, preparation and updating of its own tax risk profile would require little additional cost.

If the SEC does not prohibit external auditors from acting as accommodation parties $^{204}$ in reportable, registered or list-maintenance transactions with audited companies, audit firms' tax risk profiles should also include cumulative and current information about those accommodation party transactions. ${ }^{205}$ That information should reveal any arrangements in which an external auditor participated (or for which the auditor arranged, facilitated or established the necessary terms and conditions for a taxindifferent party's participation), if such participation is necessary to the reporting company's realization of intended tax benefits. This information about accommodation party transactions must be sufficiently specific to enable the audit committee to perform its oversight role. It should include the name of the transaction, the date entered into, a sufficient description of the structure of the transaction to permit an understanding of the source of the tax benefits, the amount of the purported tax benefit over the life of the arrangement, the amount to be realized by the audit firm from the arrangement (including any fees for advice in connection with the arrangement) and the cumulative failure rate for such transactions with the reporting company.

\section{Reporting Company Tax Risk Profile}

Each reporting company audit committee should also receive a company tax risk profile that provides objective information about the company's tax-motivated transactions. For each registered, reportable or list-maintenance transaction that the company undertakes during a reporting period, the disclosure should include a description of the tax structure, the tax benefits purported to be derived, the aggregate fees paid to advisers and the financial statement tax accruals. As in the case of audit firm profiles, a company profile should also include a statistic measuring the company's cumulative failure rate from participation in such transactions.

204. See supra note 40 and accompanying text (discussing accommodation party transactions), and supra note 85 and accompanying text.

205. An audit firm is already required to disclose any material transactions in which it participates with its client. See FINAL RULES, supra note 3 . The information here, however, would be specifically developed to promote understanding of the tax risk profile. 
Company profiles should guide audit committees (or boards) in their general task of monitoring risks to companies in aggressive tax planning arrangements and the effectiveness of companies' internal controls. It should be especially valuable to audit committees in monitoring overzealous managers who have pushed internal tax departments into abusive tax transactions. It should also ensure that there is a sophisticated "watchdog" (i.e., the external auditor) looking over the shoulder of law firms and non-audit accounting firms that provide aggressive tax-consulting services that external auditors are not permitted to provide. ${ }^{206}$ In addition, the disclosure would provide information essential to audit committees in understanding external auditors' views of tax compliance risks as reflected in financial statements.

To help audit committees assess tax strategies, they should also have information about company transactions during each reporting period as to which the overall tax treatment is uncertain ${ }^{207}$ where (1) failure of a transaction to be characterized for tax purposes as intended would have a material impact on a company's financial condition as reflected in its financial statements and (2) aggregate fees of at least $\$ 100,000$ were paid to advisers who assisted in the design and implementation of the strategy. This information would put audit committees in a much better position to understand tax accruals in financial statements. It would also provide an opportunity for audit committees to become aware of any patterns of excessive risk-taking in structured transactions in time for boards to exercise oversight and counter the "business center" mentality of internal tax and audit departments.

\section{Enhanced Disclosure in SEC Filings}

The restrained economic recovery following the burst of the high-tech bubble and the various corporate accounting scandals has been due in part to investor and lender concerns about the strength of corporate governance and credibility of reputational intermediaries. ${ }^{208}$ Arming audit committees with the ability to do their job will not suffice if investors are not convinced that corporate governance is working. The SEC already requires mandatory disclosure of operating results, ${ }^{209}$ and those results already purport to provide some understanding of the aggressiveness of a reporting company's tax positions. The SEC can and should require expanded tax risk disclosure to supplement that information, so that those who want to assess a company's tax risk have adequate information with which to do so. Disclosing information about tax risks can be

206. See, e.g., Frederick D. Lipman \& Joseph T. Gulant, SEC Proposes New Limits on Auditor Tax Services, 98 TAX NOTES 373, 374 (2003) (stating that "public companies should consider using the services of law firms or non-auditor accounting firms for tax planning services that may ultimately evolve into a prohibited legal service or a prohibited expert service," and noting that law firms may provide greater protection because of the attorney-client privilege and work product doctrine).

207. The use of the term "uncertain" is meant to include any tax-structured transaction for which a reporting company does not receive a "will" tax opinion from its tax adviser. See generally Cummings, supra note 130 (describing the significance of different levels of tax opinions).

208. See Pamela Olson, Remarks, Tax Executive Institute 53rd Mid Year Conference (Mar. 25, 2003), available at http://www.bna.com/ip/BNA/txc.nsf at 2 (last visited Feb. 24, 2004) (quoting McDonough's recent statement).

209. Mandatory disclosure requirements are at the heart of the securities laws. See generally John C. Coffee, Jr., Market Failure and the Economic Case for a Mandatory Disclosure System, 70 VA. L. REV. 717 (1984) (discussing basis for mandatory disclosure). 
done with little additional cost and is consistent with increasing interest in "social disclosure" that provides information about the social and environmental effects of corporate conduct. 210

To highlight tax planning and ensure that the public has an opportunity to evaluate it, an appropriate summary of the tax risk profiles presented to audit committees should be made part of the Management's Discussion and Analysis of Financial Condition and Results of Operations section in companies' periodic reports and registration statements. ${ }^{211}$ The tax risk information would enhance the purpose of that section to provide management's perspective. In order to be effective, the narrative should include (1) a summary of the reporting company's registered, reportable and list-maintenance transactions during the reporting period, including the company's cumulative failure rate in such transactions; (2) information about any external auditor accommodation party transactions with the company, including aggregate fees paid; and (3) information about the auditor's tax shelter consulting services, including its cumulative failure rate in taxmotivated transactions. ${ }^{212}$

\section{Strict Liability Penalties}

To strengthen the proposed disclosure requirements, Congress should enact a strict liability penalty that the SEC may apply in administrative proceedings when an auditor fails to provide the required tax risk profile to an audit committee (or when it provides materially inaccurate statistics in a tax risk profile). ${ }^{213}$ To be effective, this strict liability penalty should be at least $\$ 10,000$ "per occurrence." 114 Strict liability is appropriate to enforce a bright-line administrative reporting requirement because certainty enhances deterrence. $^{215}$

210. See Williams, Social Transparency, supra note 152 (arguing that the SEC should require expanded social and environmental disclosure to promote transparency about reporting companies' social responsibility). See also Williams, Corporate Social Responsibility, supra note 152 (discussing the need for enhanced transparency regarding environmental and social responsibility issues in a global economy).

211. Item 303 of Regulation S-K, 17 C.F.R. $\S 229.303$ (2003). See also CONCEPT ReLEASE ON MANAGEMENT's DisCUSSION AND ANALYSIS OF FINANCIAL CONDITIONS AND OPERATIONS, Exch. Act Rel. No. 33-6711 (Apr. 17, 1987) (explaining purpose of MD\&A). New rules under Sarbanes-Oxley $\S 401$ (a) already require additional MD\&A disclosure to improve transparency regarding a reporting company's off-balance sheet arrangements and contractual obligations. See Disclosure in Management's Discussion and Analysis about Off-Balance Sheet Arrangements and Aggregate Contractual Obligations, Exch. Act Rel. Nos. 33-8182, 3447264, FR-67, File No. S7-42-02 (Jan. 28, 2003), available at http://www.sec.gov/rules/final/33-8182.htm (last visited Oct. 15, 2003).

212. This description of the MD\&A disclosure assumes that the SEC will ban auditor provision of tax consulting in respect of registered or reportable transactions (or transactions for which list maintenance is required) with an audit client. If not, the MD\&A disclosure should also break out in a separate category the information about those transactions between the reporting company and its audit firm.

213. Congress has considered permitting the SEC to apply penalties in its civil administrative proceedings. See, e.g., SEC Civil Enforcement Act, S. 183, 108th Cong. (2003) (a proposal by Senator Levin allowing the SEC to assess civil money penalties in a variety of situations); The Securities Fraud Deterrence and Investor Restitution Act of 2003, H.R. 2179, 108th Cong. $\$ 3$ (2003) (similar proposal by Richard Baker in the House of Representatives). Such a penalty regime, if passed, should also apply to these proposed disclosure requirements.

214. Each material omission should count as a separate occurrence for this purpose.

215. See, e.g., Frank Partnoy, Barbarians at the Gatekeepers? A Proposal for a Modified Strict Liability Regime, 79 WASH. U. L.Q. 491, 535 (2001) (suggesting that a strict liability regime may be necessary because 
A strict liability penalty for gross understatements of tax accruals may also be appropriate. This penalty should ensure that auditors act in the public trust to protect shareholders' interests when reporting companies engage in tax-motivated transactions marketed by other accounting, banking or law firms. A firm's tax shelters are often clones of strategies marketed by other firms, ${ }^{216}$ and accountants may be prone to an attitude of "you scratch my back; I'll scratch yours" towards other firms' strategies, leading to inadequate review of tax accruals. ${ }^{217}$ A strict liability penalty should cause auditors to decide accrual issues conservatively. Given the likely inclination of auditors to provide only cursory review (and minimal tax reserves) for tax transactions that are substantially similar to ones that they themselves have structured, this penalty must be severe to be effective. At the same time, a high threshold may be appropriate to avoid over-penalizing auditors for reasonable mistakes in judging potential tax risks. An appropriate penalty might therefore require an auditor to disgorge to the government all audit fees received from a reporting company during a year (plus interest) if (1) during that year the company engaged in a transaction a significant purpose of which was tax avoidance, (2) the company must later pay a tax liability in respect of that transaction, and (3) the liability exceeds the audited statement's related tax accrual by more than a significant threshold amount (perhaps 50\%). ${ }^{218}$

\section{CONCLUSION}

The evidence of accounting firm involvement in the tax shelter industry is undeniable. The traditional permissive stance towards auditor tax consulting has already proven itself unreasonable, most conspicuously in the Arthur Andersen collusion with Enron in tax-motivated transactions that had immediate financial statement results and in the Ernst \& Young provision of tax shelter advice to Sprint executives, resulting in the necessity of firing either auditor or executives. Several factors propel the current shelter business, including underenforcement, the trend towards treating corporate tax and finance departments as revenue generators, the conflicting roles of auditors who provide aggressive tax planning, and inadequate information about tax risks. The apparent

(1) high litigation hurdles generally permit reputational intermediaries such as tax advisers to escape penalties for errors that result from conflicts of interest and (2) lucrative consulting fees provide a strong incentive to promote risky tax transactions once the adviser "get[s] past" doing something that may be wrong).

216. See, e.g., Beale Comment Letter, supra note 131, at 768.

217. See Wolfman, supra note 192 (considering it "bizarre" that a firm might call attention to the vulnerability of a product sold to its audit client by another accountant firm when the audit firm has sold similar shelters to many of its own clients). See also ENRON TESTIMONY, supra note 62 (discussing the cozy relationship among different advisers to Enron).

218. If the SEC permits auditors to continue to provide tax shelter advice to audit clients or serve as accommodation parties in client shelters, auditors should at least face a failed transaction penalty requiring disgorgement of all audit and consulting fees (with interest) for the year of the failed transaction. This strict liability penalty should apply whenever (i) an external auditor advises an audit client in connection with a registered, reportable, or investor-list maintenance transaction (or organizes, structures, participates as an accommodation party in or has any other direct involvement in such transaction) and (ii) that transaction fails to achieve more than a de minimis portion of the intended tax benefit as set out in the engagement documents. In order to limit the penalty to non-trivial cases, it should apply only if the IRS challenges the position as a tax avoidance transaction and a final determination results in the reporting company's owing additional taxes (excluding interest and penalties) of some threshold amount (perhaps $\$ 250,000$ ). 
correlation between aggressive accounting and aggressive tax planning suggests that tax risk information can be an important analytic tool for audit committees and investors.

This Article proposes, therefore, that the SEC use the corporate tax shelter regulations to demarcate permissible non-audit tax consulting for audit clients. Objective information about reportable and list-maintenance transactions should also be provided to audit committees, in the form of audit firm and reporting company tax risk profiles. Audit committees can thus be armed to exercise appropriate oversight over internal controls, select external auditors, and evaluate the risks of having external auditors perform nonaudit tax services. The information can be shared with investors through the MD\&A section of periodic reports and registration statements. Congress should reinforce these requirements by permitting the SEC to levy strict liability penalties in its proceedings for failure to disclose (and possibly for gross understatement of tax accruals). The effect of these changes would be to put auditors back where they belong-as the public's watchdog snipping at the tail of advisers (especially law firms and other accounting firms) that give their blessings to aggressive tax strategies. Incidentally, the corporate tax shelter problem should suffer a further blow.

The SEC should consider other ways that a cooperative, multidisciplinary approach could enhance its functions. ${ }^{219}$ Commentators have suggested the need to coordinate the various schedules that reconcile book and tax differences. ${ }^{220}$ The level of certainty required for offering tax shelter opinions and for determining tax accruals in financial statements might also benefit from coordination. ${ }^{221}$ An informal, interagency group should consider these issues in the intersection of the tax and securities laws.

219. See, e.g., supra note 195 and accompanying text.

220. See Olson, supra note 208 (noting Treasury consideration of possible revisions to Schedule $M$ that reconciles book and tax income for corporate tax returns); I.R.S. News Release, supra note 177 (proposing new Schedule M-3); Peter C. Canellos \& Edward D. Kleinbard, Viewpoint, Disclosing Book-Tax Differences, 2002 TNT 156-43 (Aug. 13, 2002) (suggesting conforming the tax and accounting schedules "into a single public financial statement-tax reconciliation schedule"); MILLS \& PLESKO, supra note 177 (proposing a more extended reconciliation of book and tax items); The Corporate Accountability Tax Gap Act of 2003, H.R. 1556, 108th Cong. (2003) (bill introduced by Representative Doggett requiring corporations to provide tax information to shareholders); Lee A. Sheppard, Enron's REMIC Deals: Tax Shelter or Attractive Nuisance, 98 TAX NOTES 1488 (2003) (discussing Congressman Doggett's bill).

221. See supra notes 129-135 and accompanying text (discussing inadequacy of standards for tax advice and differences between lawyer and accountant standards). 